University of Louisville

ThinkIR: The University of Louisville's Institutional Repository

Electronic Theses and Dissertations

$12-2006$

\title{
The introduction of Christianity into Scandinavia, Iceland, and Finland.
}

Tracy Marie Legel 1974-

University of Louisville

Follow this and additional works at: https://ir.library.louisville.edu/etd

\section{Recommended Citation}

Legel, Tracy Marie 1974-, "The introduction of Christianity into Scandinavia, Iceland, and Finland." (2006). Electronic Theses and Dissertations. Paper 810.

https://doi.org/10.18297/etd/810

This Master's Thesis is brought to you for free and open access by ThinkIR: The University of Louisville's Institutional Repository. It has been accepted for inclusion in Electronic Theses and Dissertations by an authorized administrator of ThinkIR: The University of Louisville's Institutional Repository. This title appears here courtesy of the author, who has retained all other copyrights. For more information, please contact thinkir@louisville.edu. 


\title{
THE INTRODUCTION OF CHRISTIANITY INTO SCANDINAVIA, ICELAND, AND FINLAND
}

\section{By}

Tracy Marie Legel

M.A., University of Louisville, 2006

\author{
A Thesis \\ Submitted to the Faculty of the \\ Graduate School of the University of Louisville \\ in Partial Fulfillment of the Requirements \\ for the Degree of
}

Master of Arts

Department of History University of Louisville

Louisville, Kentucky

December 2006 


\title{
THE INTRODUCTION OF CHRISTIANITY INTO \\ SCANDINAVIA, ICELAND, AND FINLAND
}

\author{
By \\ Tracy Marie Legel \\ M.A., University of Louisville, 2006
}

August 2006

by the following Thesis Committee:

Thesis Director 


\section{DEDICATION}

This thesis is dedicated to Carrie Ann Saghy Kilbane who has always inspired me in both my educational and professional endeavors. 


\section{ABSTRACT \\ THE INTRODUCTION OF CHRISTIANITY INTO \\ SCANDINAVIA, ICELAND, AND FINLAND}

\section{Tracy Marie Legel}

August 17,2006

The conversion of Scandinavia, Iceland and Finland occurred over many years and resulted in the formation of Scandinavian monarchies, a strong Icelandic parliament, and an loosely organized Finnish nation. The conversion of Northern Europe was completed Viking style with aggressive tactics, involvement of few as outside leaders as possible, and reward seeking converts. Viking explorations introduced the Northern European communities to Christianity and Northern Europeans acknowledged the religion in their own societies even though they did not completely embrace it. When their status quo was upset, Northern Europeans looked to Christianity as a solution to their woes. Promoted by the leaders of Northern European societies and forced upon the masses, Northern Europeans eventually pledged their loyalty to the Christian God, and 
accepted Christian customs. As more Christian beliefs were accepted, Northern Europeans became more integrated into the European society. The conversion transformed Scandinavia, Iceland and Finland politically, socially, and economically. 


\section{TABLE OF CONTENTS}

Chapter 1 - Introduction........................................... 1

Chapter 2 - Denmark ............................................... 13

Chapter 3 - Norway............................................ 35

Chapter 4 - Iceland .................................................... 51

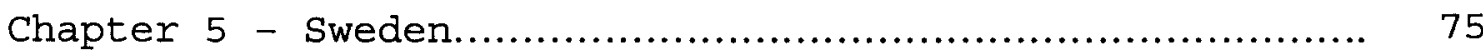

Chapter 6 - Finland.............................................. 89

Chapter 7 - Conclusion ............................................ 106

References .......................................................... 110

Curriculum Vitae...................................................... 116 


\section{Chapter 1}

INTRODUCTION

The study of the introduction of Christianity in Scandinavia is best described by S. A. Dunham in his 1839 work History of Denmark, Sweden, and Norway: "Nothing can be more obscure than the origin of Christian worship in these regions." ${ }^{1}$ Even in the nearly two centuries since Dunham's work, few historians have focused on how Christianity was introduced to the Northern Europeans. In this explanation the various aspects of the conversion process in Denmark, Norway, Iceland, Sweden, and Finland it is obvious that the conversion of Scandinavia, Iceland and Finland occurred over five hundred years and resulted in the formation of distinct Northern European nations.

In studying the conversion of Scandinavia, Iceland and Finland, the fundamental challenge is defining define 'conversion'. Conversion can mean the receiving of monotheistic vows, the support of church authority, the acceptance of new rituals, or the tolerance of outside

${ }^{1}$ S. A. Dunham. History of Denmark, Sweden, and Norway. Volume II London: 1893 page 151. 
beliefs. Because of the ambiguity in the definition of conversion, it is impossible label the specific moment when the conversion of Scandinavia, Iceland and Finland occurred.

Christianity in Scandinavia, Iceland and Finland entered through a variety of different ways and was ultimately accepted by all of these states but the effect of the conversion was different in each of these areas. In Scandinavia, the acceptance of Christianity occurred at the same time the nations of Denmark, Norway, and Sweden developed their monarchies. In Iceland, however, the acceptance of Christianity strengthened the importance of the Althing, Iceland's parliament. In Finland, the acceptance of Christianity helped organize the tribes in the northern territory but ultimately brought them under Swedish control. In the northern territories, a symbiotic relationship existed between each conversion and the development of each Northern European Nation.

The Northern Europeans' acceptance of Christianity was more than just a change in religion; through the conversion process the North changed politically, socially, and economically. Once they were no longer isolated culturally, the Northerners' wealth increased and their interest in the outside world grew. Both political and 
social issues underlie the Northern conversion process. Northern kings, motivated by a desire for power, appreciated the organizational power of the Church and encouraged their subjects to accept baptism. Kings throughout mainland Europe and England were desperate to stop the Viking attacks and sought to introduce Christian values to the Northerners. Foreign missionaries were also interested in the Christianization of Northern Europe as a way to gain favor and recognition from the Church hierarchy .

Although Scandinavian kingdoms ultimately accepted Christianity, subtle differences exist as to how each kingdom converted. Denmark was the first to encounter missionaries, most notably Anskar, the Apostle of the North. Anskar was also important in the conversion of Sweden, but the remote kingdom took much longer to convert. Foreign missionaries were also prevalent in Norway, but conversion did not occur until strong Norwegian leaders, Olaf I and II, fought and died while promoting the religion. Iceland was introduced to Christianity by very violent missionaries, presumably from Norway, but ultimately the religion was legally accepted as a way for the country to maintain independence and keep the peace. Finland converted much later and had influences from both 
the East and the West. However, information on its conversion is very scarce and sources are unreliable.

Frequent contacts established through Viking expeditions between the North and the rest of Europe had a significant impact on the Northern Europeans. ${ }^{2}$ Partly due to its geographical location, the North was slow and furtive in its conversion. In addition, pagans were steadfast in their ways and firm in their beliefs. The conversion of Scandinavia, Iceland, and Finland started with the missions in the early $7^{\text {th }}$ century and continued until to the establishment of a Catholic hierarchy. It took over five hundred years from the time missionaries first made contact with the Northern Europeans before Christianity was adopted.

During the conversion period from the tenth to the twelfth centuries, a ruling class was developing and the middle class was growing in Northern Europe. The absence of strong centralized governments hindered the advancement of the new faith but as the Church developed in these countries, their political systems advanced. Culturally, the peoples from the North admired the wealth and customs

${ }^{2}$ It is unclear if Viking expeditions began as a reaction to external challenges or if the Vikings initiated the contact. However, the Vikings made no real efforts to spread paganism to the areas they conquered. 
of Western Europe. By the tenth century, Christianity dominated western and central Europe and the Christianization of Northern Europe had begun. Christianity formally split into Catholic and Eastern Orthodox divisions in 1054. At that time the Catholic religion was well established in Denmark, Iceland, and Norway but did not become established until much later in Sweden and Finland; which accepted the religion by the midtwelfth century and the thirteenth century respectively. Through the acceptance of Christianity, the Northern Europeans assimilated into the societies they formerly had attacked.

For the most part, the history of Scandinavia, Iceland and Finland during Viking times was written by foreign authors many years after the conversions occurred. Before 1200, Northern Europe is only briefly mentioned in the writings of early historians, if at all. Often, these sources are unreliable as the outsiders did not understand the culture of the Northern Europeans, whom they greatly feared. With few exceptions Northern European written histories are limited to historical romances in the form of sagas. At the time of conversion, Northern Europeans began recognizing the importance of learning to write. 
The major primary sources used include Bishop Rimbert's Vita Ansgarii, Adam of Bremen's History of the Archbishops of Hamburg-Bremen, Ari Thorgilsson's Íslendingabók, and Snorri Sturluson's Heimskringla. All of these sources provide information about when and where events occurred in the conversion of Scandinavia and Iceland. In addition, they also provide insight as to the beliefs and values of the missionaries and the Scandinavians at the time of conversion.

Bishop Rimbert was responsible for the chronicles of Anskar's life in Vita Ansgarii, an important source for ninth century Scandinavian history. Written shortly after Anskar's death, it is a valuable as it appears to be accurate in its details. Vita Ansgarii provides many details of Anskar's life and the politics of dealing with the Vikings and the Christian Church. However, Rimbert often exaggerates Anskar's charm and success. Regardless of Rimbert's prejudices, the book furnished valuable insight into a time when there is little history but many legends.

In the 1070s, Adam of Bremen, a German ecclesiastical historian, composed his History of the Archbishops of Hamburg-Bremen, an important source for Danish history. Because of the importance of Hamburg-Bremen in the 
conversion of Scandinavia, this work provides valuable information on all of the Northern Europeans countries and the Christian missionaries. However, Adam is an ardent promoter of Hamburg-Bremen and does not credit the AngloSaxon missionaries much. Although Adam of Bremen did not favor the English missionaries and detested pagans, his work is a valuable source of Scandinavian history and of the conversion of the North.

Saxo Grammaticus is the first notable Danish historian. His Gesta Danorum or Historia Danica played an important part in the history of Danish literature. Saxo was commissioned to write the history by Archbishop Absalon of Lund. The work is a collection of sixteen books, the first nine of which contain mostly mythological and legendary material (and interestingly, the basis of Shakespeare's Hamlet). The last seven books, which are thought to have been written first, contain historical information based on oral communications. Saxo used many sources, particularly the heroic poetry and runic inscriptions common among the scandinavians to develop his literary works. Through this work, saxo managed to preserve early Danish literature.

Iceland has an abundance of primary sources regarding its conversion. Seeking to define themselves as a nation 
with a place in the world, the Icelanders recorded their modest beginnings. In order to show their independence and develop a new identity, Icelanders were more than willing to record their political birth as a nation. Íslendingabók, composed between 1125 and 1132, by Ari Thorgilsson the Wise, discusses the historical and political activities of the Icelanders from 930 to 1030 at the zenith of the Icelandic commonwealth. Although only an abridged version survives, the abridgment contains genealogies and accounts of kings' lives omitted in the complete work. Íslendingabók is exceptional because it is the first history of Iceland written in the vernacular.

Ari, who lived from 1067 until 1148, was an exceptional historian. He was a priest chieftain educated at Hankadulr in Southern Iceland by Teitr Isleifsson, the son of the first. Icelandic bishop. Ari was a superior historian and narrator who often cited the sources of his information, such as his uncle, Thorkel Gelisson, and his mother. Ari was probably involved with the writing in the early twelfth-century of the Landnamabók: the Book of the Settlements, which contains topographical information and lists about 400 early settlers of Iceland. Throughout the saga age, Landnámabók served as a source for many family sagas. 
Heimskringla (Chronicles of the Kings of Norway), by Snorri Sturluson(1178-1241), is another exceptional primary source which contains sixteen sagas of Norwegian history and records the kings of Norway from the earliest times to 1177, as well as a collection of their sagas and poems. The history combines traditional legend with substantial historical information and is of superb literary merit. Snorri Sturluson, the author of the Heimskringla, was an Icelandic poet, historian, and chieftain, and a leading figure in medieval Norse literature. Snorri's appreciation of drama was outstanding. Furthermore, his writing is remarkable because of its scope and authenticity. Snorri Sturluson's Heimskringla provides vivid accounts of the Norwegian Kings and their attempts to Christianize Norway and surrounding areas. Although his work tends to be a bit overzealous, it is valuable in understanding the conversion of Norway and the force used to complete the transformation of the pagans. This work is very well written and a great source for information about this time period in Norway.

Although not normally considered primary sources, sagas concerning the conversion to Christianity and the Icelandic church from the thirteenth century had some historical basis and provide a glimpse into life in early Iceland. Although these sagas tend to be very subjective, 
they are fascinating and colorful stories which provide historians a glimpse into medieval Icelandic culture. The stories center on the family vendettas; journeys to England, Ireland, France, and Russia; love; and the bravery of the Vikings. Although sources sometimes differ on certain dates, one can still decipher the approximate time events occurred. For example, the Kristni Saga, not available in English, discusses the coming of Christianity to Iceland. Njals Saga deals with the legal and political growth of Icelandic society into a stable community of settlers at the time of the conversion (c. 1000) but includes human emotions such as rivalry, loyalty, love, and jealously. The Laxdaela saga is a classic love triangle story with regards to a powerful wealthy Icelandic family. All of these sagas reviewed collectively provide a valuable insight into the life and values of the early Icelanders. These works have some historical basis as they show the beliefs of the early Icelanders and interactions with the rest of Scandinavia.

One of the chief problems in addressing the conversion of Finland is the lack of primary sources; there are no Finnish primary sources for this period in Finnish history. The only information available on this area of history is through archeological artifacts and somewhat later 
accounts, many of which were written elsewhere by foreign authors. The problem with archaeological artifacts is that they are limited in scope, context, and readability. The problem with secondary sources is that the authors have in some cases very strong prejudices or biases. For example, the roles of King Erik, St. Henry, and Nicholas Breakspeare (Pope Adrian IV) in the conversion of Finland may have been exaggerated by foreign authors seeking to further elevate Breakspeare's role in the Northern conversion process. In addition, a discrepancy exists between the eighth and twelfth centuries regarding the date of the Finnish conversion. But this may be simply explained by the simple difference between the definition of introduction and adoption. Although the Finns were introduced to Christianity before the eighth century, the country did not adopt Christianity until after the organized missions entered Finland in the mid-twelfth century. Another problem relates to the influence of Christianity from both the East and West. Both forms of Christianity influenced Finland, but the western missions were given considerably more attention in the history books, probably because Finland ultimately embraced western Christianity.

Sources on the subject of the conversion of Scandinavia, Iceland and Finland are scarce and unreliable. 
At times in the history books, Northern European disappears and is rarely mentioned, leaving large gaps in the history of the area. Most histories on the subject for the conversion of Northern Europe are incomplete and unreliable. However, when the many pieces of the puzzle of its history are put together it becomes possible to get a glimpse of the motivations and developments which led to and allowed for conversion of the North. This is my contribution to Northern European history throughout the time of conversion. 
CHAPTER 2

DENMARK: A CONVERSION FOR POWER

Geographically enclosed by smaller forests in the south and larger forests to the north, Denmark was a remote northern territory and not of much interest to early Christian missionaries. However, around 700 A.D. the unification of Denmark began and by 800 , Denmark is regularly mentioned in literary works. As Denmark organized into a state, it also began to accept Christianity. ${ }^{1}$

Before the conversion to Christianity, the Danes practiced a traditional North German paganism - a polytheistic pantheism including animal sacrifices and occasionally human sacrifices, and exhibiting distinct burial methods such as burning the dead to speed the access to the afterlife or adding grave goods to protect and oversee the dead. As in the other areas of Scandinavia, worship services occurred at chieftains' farms. For example, artifacts reveal that Lejre, the capital of the

\footnotetext{
${ }^{1}$ Erik Kjersgaard, A History of Denmark. (Copenhagen: Royal Danish Ministry of Foreign Affairs, 1974) Page 11.
} 
Zealand Province and now a small village near Roeskilde, was a sacred place for pagan worship. ${ }^{2}$

In the early ninth century, as the Frankish empire sought to expand and the Vikings simultaneously extended their raids, Christianity became more familiar to the Danes. ${ }^{3}$ The first known missionary in Denmark (and first in Scandinavia), was the English missionary, Willibrord, bishop of Utrecht, who tried to convert the king of the Danes, Ongendus, at the beginning of the eighth century (around 710). It is believed that ongendus allowed Willibrord to take thirty Danish boys to learn Christianity. Alcuin in his "The Life of willibrord" explained:

At that time, so we are told, the Danish ruler was Ongendus, a man more savage than any wild beast and harder than stone, who nevertheless, through divine intervention, received the herald of truth with every mark of honour. But when the latter found that the people were steeped in evil practices, abandoned to idolatry and indifferent to any hope of a better life, he chose thirty boys from among them and hastily returned with them to the chosen people of the Franks. on the journey he instructed the youths in the faith and baptized them, so that if they perished from the long sea voyage or though the ambushes of the savage dwellers of those parts he should suffer no loss in their regard. In this way he desired to anticipate

\footnotetext{
${ }^{2}$ Birgit Sawyer, ed. The Christianization of Scandinavia. (Viktoria Bokforlag, 1987) page 31.

3 Erik Kjersgaard, A History of Denmark. (Copenhagen: Royal Danish Ministry of Foreign Affairs, 1974) page 12.
} 
the craft of the devil and to strengthen these redeemed souls by the sacraments of the Lord. ${ }^{4}$

Unfortunately, no additional reliable evidence of this mission exists and little is known of King Ongendus. Willibrord died in 739; although he was unsuccessful in Scandinavia, he was an important missionary who founded the church in Frankish Frisia: ${ }^{5}$ records indicate that as early as 776 a church existed at Meldorf. ${ }^{6}$

In the late eighth century, Charlemagne sought to expand his Frankish empire to the North. As a result Frankish merchants were able to travel the waters of Scandinavia while being protected by the army. The Saxons, led by Widukind, ruled the territory north of the Elbe. They were defeated many times by Charlemagne and in 777 Widukind fled to Denmark, seeking protection from King Sigfrid in Jutland. ${ }^{7}$

In order to further his goal of Frankish domination, Charlemagne attempted to set up missions in the North. Christian missionaries, protected by the Frankish army, began to work with the pagan population. The results were

\footnotetext{
${ }^{4}$ Alcuin, The Life of Willibrord. Talbot, C. H., editor and translator. The Anglo-Saxon Missionaries in Germany. (New York: Sheed and Ward, 1954) Page 9.

5 Margaret Deanesly, The Pre-Conquest Church in England. (New York: Oxford University Press, 1961) Pages 232-234.

6 Rimbert. Vita Ansgarii Introduction.

7 Stewart Oakley, A Short History of Denmark. (New York: Praeger Publishers, 1972) page 29.
} 
dismal, and this meddling antagonized the independentminded Danes and instigated a defensive reaction. ${ }^{8}$ In 787 , Charlemagne established a bishop's seat at Bremen with Willihad, an Englishman, as first bishop. Eventually, Widukind and the saxons, true to their independent and violent ways, sought revenge. Widukind lost, even with the help of the Wends, but his wrath was so great that Bishop Willihad was forced to abandon the mission. However, Widukind was ultimately defeated and in 785 accepted baptism at Attigny. Bishop Willihad died in 789 and was succeeded by Bishop Willerich. ${ }^{9}$

Bremen endured, but an additional mission was wanted in Hamburg. The first church in Hamburg must have been built around 804 as it was consecrated by Bishop Amalarius of Treves, a student of Alcuin, who oversaw the mission.10 Later, Charlemagne sent Heridac, a priest, to Hamburg with the intention of establishing a bishopric and eventually a See in the North. However, this effort ended with Heridac's death. ${ }^{11}$

\footnotetext{
${ }^{8}$ Stewart Oakley, A Short History of Denmark. (New York: Praeger Publishers, 1972) page 29.

9 Erik Kjersgaard, A History of Denmark. (Copenhagen: Royal Danish Ministry of Foreign Affairs, 1974) page 15.

10 William P. Barker, Who's Who in Church History. (Old Tappan, New Jersey: Fleming H. Revell Company, 1969) page 17.

11 Adam of Bremen, History of The Archbishops of Hamburg-Bremen by Adam of Bremen. Tschan, Francis J, translator. (New York: Columbia University Press, 1959) Page 19.
} 
At this time, in Denmark, King Godfred, who ruled in Jutland, fortified its southern border to keep the Franks out. Nevertheless, Frankish influence and thus Christianity penetrated into Danish society. ${ }^{12}$ Upon Godfred's death his successor, Hemming, made peace with the Franks and established a southern border on the Ejder River. After ruling only two years, however, Hemming died, and civil war erupted in Denmark between rival chieftains. ${ }^{13}$ Any centralized activity in Denmark ceased to exist as chieftains fought over power. The lack of any one strong ruler in Denmark lasted over ten years. During this time of chaos Christian influences continued creeping into Denmark. As external powers sought to conquer the land the Danes began to focus on unification.

In the second half of the eighth century, threats to the Danes' autonomy, superior ships and weapons, welldeveloped military organization, and a spirit of adventure combined to bring about the Viking Age when Vikings set out on innumerable plundering expeditions abroad. ${ }^{14}$ Viking travels to Christian Europe introduced the Scandinavian world in the North to the Christians of the South. Since

12 Erik Kjersgaard, A History of Denmark. (Copenhagen: Royal Danish Ministry of Foreign Affairs, 1974) page 15.

13 Stewart Oakley, A Short History of Denmark. (New York: Praeger Publishers, 1972) page 29-30.

14 stewart Oakley, A Short History of Denmark. (New York: Praeger Publishers, 1972) page 29. 
Charlemagne had diminished the power of the Frisians in the North Sea to keep them within his sphere of influence, this area was extremely vulnerable to Viking attacks. As the Vikings realized the wealth of Christian Europe, their raids on coastal towns and monasteries intensified. ${ }^{15}$ After Charlemagne's death in 814 , Vikings continued to raid the Frisian and Frankish lands and threatened Charlemagne's kingdom.

With leaders who had political relationships with mainland Europe, Denmark was better organized than other Scandinavian countries but, as other Scandinavian countries, it was still largely tribal. In order to control the unruly Danes, Louis the Pious, Charlemagne's son and Emperor of the Franks, attempted to convert the Danes to Christianity with the support of Rome. Seeking to advance the power of the Franks, Louis the Pious was very determined to convert the pagans to Christianity. Pope Pascal I was willing to cooperate as the Holy see had been anxious to convert the obscure North for many years. In 822 or 823 , a Danish mission at Holstein was established. Ebbo, the Archbishop of Reims, oversaw the mission with the

15 Erik Kjersgaard, A History of Denmark. (Copenhagen: Royal Danish Ministry of Foreign Affairs, 1974) page 15 
help of the monk Haltigar. ${ }^{16}$ Ebbo baptized some converts but soon returned home. Although these attempts proved futile, they continued to familiarize the Danes with Christianity. In addition, continued internal disputes in Denmark allowed the influx of Frankish influence and, thus, Christian missionaries.

The Christian missions to the North officially began to take hold in 826 when Harold Klak of Denmark became the first Scandinavian ruler to be baptized. Harold sought political support from Louis the Pious in a campaign against Horik, King Hemming's son. Realizing the power of the Christian Franks, Harold welcomed a Christian mission to Denmark. Louis was happy to convert the pagans, especially with the help of the newly baptized Scandinavian ruler. ${ }^{17}$

Anskar, a significant person in the conversion of Northern Europe, was helpful in furthering Louis' goal of converting the Danes. ${ }^{18}$ He was born in 801 ; his mother, a devout Christian, died when Anskar was five years old and he was raised the monks of the Abbey Corbie. After studying many years in St. Peter's School at Corbie, Anskar

\footnotetext{
${ }^{16}$ S.A. Dunham, History of Denmark, Sweden and Norway. Volume II (London: 1839) page 153 .

17 S.A. Dunham, History of Denmark, Sweden and Norway. Volume II (London: 1839) page 153 .

${ }^{18}$ Most of the background information on Anskar came from Rimbert's Vita Ansgarii
} 
became a teacher. He soon headed the school with another monk, Witmar. In 822, he transferred, along with Witmar and other monks, to New Corbie in Saxony, where he became master of the monastic school. He taught for four years at New Corbie. At that time, the exiled King of the Danes, Harald Klak, came seeking aid from the Franks. Although 826 was a year of relative peacefulness, the memory of previous Viking assaults scared off anyone who wanted to return to Denmark with Harold to Christianize the pagan people. After the baptism of Harold Klak, Louis the Pious summoned a council to debate the matter, and Abbot Wala of Corbie recommended that Anskar lead the mission in Denmark. ${ }^{19}$ A successful clerical politician and ambitious missionary, Anskar also had a charismatic personality. As Rimbert noted:

In everything that he did God's grace was with him, as we have proved by many examples. For inasmuch as he was solicitous for the protection of his flock, he won the right to see heavenly visions and in many cases, as we have shown, his mind was inspired by the sight of things divine. Moreover, as the grace of God shone more and more in his body, his preaching had a special charm, though it was at times awe inspiring, so that it might be clearly seen that his words were controlled by divine inspiration. By mingling gentleness with terror he would make manifest the power of God's judgment, whereby the Lord when He comes will show Himself terrible to sinners and friendly to the just. His grace of speech and appearance were so attractive that he inspired with

19 Rimbert. Vita Ansgarii. Ch VII Page 14. 
fear the powerful and rich and still more those who were impenitent and shameless, and whilst the common people embraced him as a brother, the poor with utmost affection venerated him as a father. ${ }^{20}$

Anxious to spread the Christian faith, Anskar traveled with Brother Autbert and engaged in missionary work at Schleswig. However, the mission ended in 827 when Harold Klak was exiled by Horik. The Church supported the losing side, but from this experience Horik quickly realized the power of Christian support and the effectiveness of its organization. ${ }^{21}$

The Schleswig mission further suffered when Brother Autbert fell ill. Discouraged, Anskar and his mission returned to Corbie where Brother Autbert died. ${ }^{22}$ Soon after Anskar's return, King Bjorn of Sweden feared an assault from Horik of Denmark. Appreciating the political advantage of allying with the Franks, King Bjorn sought the aid of Louis the Pious and invited Louis to send a mission to Sweden. Eager to continue the mission, Louis requested that Anskar lead the mission and Anskar happily obliged. Anskar was successful in baptizing Herigar, the governor of Birka, who built a church and worked in the mission for

20 Rimbert Vita Ansgarii. Chapter XXXVII.

21 Rimbert. Vita Ansgarii. Introduction.

22 Rimbert. Vita Ansgarii. Chapter 9. 
many years. ${ }^{23}$ After founding the mission, Anskar and Witmar returned home in $831 .^{24}$

Upon their return, Louis the Pious again decided to try to establish a see for the Danish people north of the Elbe River. Louis established an archiepiscopal see at Hamburg in 831 and appointed Anskar as archbishop. At this time, there were four baptismal churches in Denmark, in Hamburg, Heiligenstedten, Schonefeld, and Meldorf. ${ }^{25}$ To confirm his new appointment, Anskar traveled to Rome to obtain papal approval. Pope Gregory IV not only approved of his position in Hamburg but he also dispatched Anskar as papal legate to the Scandinavians, placing the whole of Scandinavia under his jurisdiction. ${ }^{26}$

For the next fourteen years, Anskar labored at his missionary works at Hamburg. Although conversion was difficult, Anskar persisted. As Rimbert explained:

Meanwhile our lord and master diligently executed his office in the diocese that had been committed to him, and in the country of the Danes, and by the example of his good life he incited many to embrace the faith. ${ }^{27}$

When Anskar ran out of people willing to convert, he bought pagan slaves from the Vikings and instructed, baptized, and trained them. Anskar was aided in his missionary work by

23 Rimbert. Vita Ansgarii. Chapter 11.

24 Rimbert. Vita Ansgarii. Introduction.

25 www.ccel.org

26 Rimbert. Vita Ansgarii. Ch XIII

27 Rimbert. Vita Ansgarii. Chapter XV. 
the monastery in west Flanders at Torhout and monks from Corbie. ${ }^{28}$

In 840 , Louis the Pious died and his kingdom was divided among his three sons, Lothar, Louis the German, and Charles the Bald. The partitioning of the Frankish kingdom in 843 signaled the end of the Frankish empire and, as a result, seriously hurt Anskar's mission. Louis' three sons were divided in not only their rule, but in their opinion of Anskar's mission. Torhout was under the rule of Charles the Bald, who did not support the mission. The loss of control in this area, and thus its source of income, hurt the Hamburg mission. Louis the German, who ruled the East Frankish kingdom, which encompassed the Hamburg See, was more interested in political gain than in Christianizing the heathens and ignored Hamburg. But the mission suffered the greatest strike in 845 when King Horik of the Danes attacked Hamburg. The Danes were initially defeated, but rallied and destroyed the Hamburg mission, along with all of its possessions. As a consequence, Anskar moved the see to Bremen, which was under the control of Lothar, and became the archbishop by $849 . .^{29}$

At the new location, Anskar's missionary work was quickly revived. Bremen was soon united with Hamburg by

\footnotetext{
28 Rimbert. Vita Ansgarii. Chapter XV

${ }^{29}$ Rimbert. Vita Ansgarii. Introduction.
} 
Pope Nicholas I. Through his continued missionary work throughout the area, Anskar won the friendship of Horik, the Danish king whose ships had raided Hamburg just three years earlier. This friendship allowed Anskar to continue his work, building the first Danish church in Schleswig and establishing schools. In 852, Anskar followed his calling and resumed his missionary activities in sweden. Once he felt his work had a foundation in Birka, Anskar returned to Bremen. ${ }^{30}$ Upon returning to Bremen, Anskar continued to work to Christianize the North and established churches at Hedeby and Ribe.

In 854, King Horik died. Although the Danish kingdom remained essentially intact, little is know about who ruled in Denmark. ${ }^{31}$ Anskar continued his missionary work in Bremen until his death on February 3,865 . Shortly after his death, Anskar was canonized by Pope Nicholas I. Anskar has been granted the title "Apostle of the North."

Unfortunately, after Anskar's death many of the areas he worked so hard to convert relapsed into paganism, thus indicating how superficial the initial conversion of the North was. Anskar's successor, Rimbert, kept the spirit of the mission alive but was not very successful. While many

\footnotetext{
${ }^{30}$ Rimbert Vita Ansgarii. Introduction.

31 Stweart Oakley, A Short History of Denmark. (New York: Praeger Publishers, 1972) page 23.
} 
view Anskar's missions as ultimately failing, Anskar was instrumental in introducing Christianity to Denmark and Sweden. Through his efforts, Anskar was able to build the first Christian churches in these areas of Scandinavia. As Scandinavian kings began to understand Christianity and the political benefit of a unified Church, the leaders began to embrace the religion. It was a slow process, though, as Christianity did not actually take hold until the Scandinavian leaders of the tenth and eleventh centuries began to adopt and spread the faith and, subsequently, capitalize on its power.

In the $870 \mathrm{~s}$ the Vikings overran much of northern and eastern England. In early 878, under the leadership of Guthrum, the Danes invaded Wessex and took control of three-fourths of the Anglo-Saxon kingdom. However, Alfred the Great rallied and defeated the Danes at Ethandum in early spring. Under the terms of the Treaty of Wedmore, Guthrum agreed to be baptized with King Alfred of Wessex as his godfather. ${ }^{32}$ This pattern of events was memorialized in The Life of King Alfred by Asser,

The next morning [Alfred] removed to Edington, and there fought bravely and perseveringly against all the army of the pagans, whom; with the divine help, he defeated with great slaughter, and pursued them flying to their fortification. Immediately he slew all the

32 Ewan Butler, Scandinavia. (New York: American Heritage Publishing Co., Inc, 1973) page 20 . 
men, and carried off all the booty that he could find without the fortress, which he immediately laid siege to with all his army; and when he had been there fourteen days, the pagans, driven by famine, cold, fear, and last of all by despair, asked for peace, on the condition that they should give the king as many hostages as he pleased, but should receive none of him in return, in which form they had never before made a treaty with any one. The king, hearing that, took pity upon them, and received such hostages as he chose; after which the pagans swore, moreover, that they would immediately leave the kingdom; and their king, Gothrun, promised to embrace Christianity, and receive baptism at king Alfred's hands. All of which articles he and his men fulfilled as they had promised. For after seven weeks Gothrun, king of the pagans, with thirty men chosen from the army, came to Alfred at a place called Aller, near Athelney, and there King Alfred, receiving him as his son by adoption, raised him up from the holy laver of baptism on the eighth day, at a royal villa named Wedmore, where and the holy chrism was poured upon him. After his baptism he remained twelve nights with the king, who, with all his nobles, gave him many fine houses. ${ }^{33}$

Once again, another Scandinavian king was baptized, though it was a king of the Scandinavian holdings in England. Slowly, Christianity was being accepted by the Viking leaders; however, Scandinavia as a whole remained pagan. Bishop Rimbert, Anskar's successor, died in 888 . Although Rimbert was succeeded by Adalgar and the bishopric remained, Bremen exhibited little interest in the northern areas for nearly fifty years. In 892, Pope Formosus decided

33 Asser. The Life of King Alfred.

http: //sunsite.berkeley.edu/OMACL/KingAlfred/part1.html 
Hamburg-Bremen should remain unified until Hamburg was able to support sees of its own. ${ }^{34}$

In 936, Unni, a successor of Anskar as archbishop of Hamburg-Bremen, visited King Gorm of Denmark. ${ }^{35}$ Unni's name appears in conversion histories but no information exists about his life. However, it is noted that Pope John $\mathrm{X}$ sent Unni his pallium. ${ }^{36}$ King Gorm and his wife are regarded as nation-builders as during whose reign Denmark established notable boundaries. King Gorm's Jelling stone in Jutland proclaims, "King Gorm erected this memorial to Tyra his wife, glory of Denmark." 37 Some historians reject Adam of Bremen's account of Unni's meeting with King Gorm. ${ }^{38}$ Regardless of whom he met, Unni's visit marks another phase in the slow systematic conversion of Denmark. Unni next sought to recall the Swedes to Christianity and traveled to Birka. Unni survived only a few months and died in Birka on September 17, 936. Although Unni's missionary work in

\footnotetext{
34 www. newadvent.org

${ }^{35}$ Adam of Bremen, History of The Archbishops of Hamburg-Bremen by Adam of Bremen. Tschan, Francis J, translator. (New York: Columbia University Press, 1959) Page 50.

${ }^{36}$ C.J.A. Opperman page 50.

37 Stewart Oakley, A Short History of Denmark. (New York: Praeger Publishers, 1972) page 32 .

38 Gwyn Jones, A History of the Vikings. (Oxford: Oxford University Press, 1994) Page 113. "Even so, Adam is an incorrect witness in that he puts Gorm on the throne too early, and a cantankerous or biased one in that he describes him as a malignant prosecutor of Christians."
} 
Denmark was limited, his visits revived the missionary work in the North and thus had a major impact on its conversion. The son of King Gorm, Harald I or Harald Bluetooth, a devout Christian, ruled as King of Denmark from 940 to 985. During Bluetooth's reign, the faith proceeded slowly but without serious conflicts. In 948 a bishopric was established in Schleswig. Bluetooth completed the country's unification initiated by his father and furthered the attempts to convert the Danes to Christianity. Harald was baptized sometime in the 960 s by Bishop Poppo, who impressed the king with his miracles such as carrying a hot iron without anguish. ${ }^{39}$ King Harald probably also became a Christian to appear as an advocate against pagan religion, and thus evade German meddling in the affairs of Denmark. ${ }^{40}$ While his initial motivation may have been to convert for political reasons, he seemed to take pride in his conversion. After his baptism he transformed his father's pagan tomb into a Christian place of worship. ${ }^{41}$

Bluetooth oversaw the efforts of the newly appointed bishops of Jutland, under the guidance of the archbishop of Hamburg-Bremen, to Christianize the kingdom. In 947 or 948 ,

39 C.J.A. Opperman page 53.

40 Stewart Oakley, A Short History of Denmark. (New York: Praeger Publishers, 1972) page 34-35.

41 Erik Kjersgaard, A History of Denmark. (Copenhagen: Royal Danish Ministry of Foreign Affairs, 1974) page $17 \& 18$. 
Archbishop Adaldag consecrated bishops for Schleswig, Ribe, and Aarhus (Oldenburg came later) but it is unclear if these bishops ever made it to Denmark. ${ }^{42}$ Harald's power extended into parts of Norway and Sweden and thus furthered the advancement of Christianity in the North. However, at Harald's death, Christianity still did not have a firm place in Denmark. Interestingly, Bluetooth was proud of his efforts to Christianize the North as his Jelling Stone boasts, "The Harald, who . . made the Danes Christians."43 The Christian Church continued its missionary efforts by establishing and supporting bishoprics as well as building churches throughout the North. These efforts were further advanced as the rural community in Denmark began to organize in accordance with contemporary Christian social standards with an influential clergy, landowning chieftains, rapidly developing middle class, and a large peasantry

Harold's son and successor, Svend Forkbeard, was not a strong opponent of Christianity but thought the archbishop of Hamburg-Bremen had too much influence over political affairs in Denmark. Svend was supported politically by many pagan groups which approved of his distrust of the

42 S. A. Dunham, History of Demark Norway and Sweden. Vol. II, (London: 1839) page 162-163.

43 Stewart Oakley, A Short History of Denmark. (New York: Praeger Publishers, 1972) page 34 . 
Hamburg-Bremen missionaries. In 1013 Svend conquered England and invited English missionaries to Denmark to counteract the power of the Hamburg-Bremen archbishops. ${ }^{44}$ Despite his attempt, Denmark remained under the influence of the German bishops. Although Svend's invitation to the English missionaries aided in the spread of Christian influence throughout Denmark, there was a notable pagan reaction to the increase in popularity of Christianity. When Svend died in 1014, Christianity was still only tenuously established. ${ }^{45}$

In 1016, Harald's grandson and Svend's son, Canute, ascended to the throne of the great Anglo-Scandinavian patrimony, which included Denmark and England (and eventually included southern sweden in 1028 and Norway in 1030). Canute sought to strengthen the ties between the Nordic and Christian cultures. About the same time he became the leader of the Anglo-Scandinavian kingdom, Canute was baptized by Ethelnoth the Good, who later became the archbishop of Canterbury. Canute's reign inaugurated the transformation of Viking Scandinavia and Denmark as Christianity flourished throughout his territories. To provide a measure of unity throughout his diverse holdings,

\footnotetext{
44 Stewart Oakley, A Short History of Denmark. (New York: Praeger Publishers, 1972) page 35.

45 Stewart Oakley, A Short History of Denmark. (New York: Praeger Publishers, 1972) page 35-36.
} 
Canute strove to support the Christian Church in the North and codify the laws. Canute was very eager to spread the Christian faith as he exclaimed in a Proclamation:

I have taken to heart the written words and verbal messages that Archbishop Lifing brought me from the pope from Rome, that I should everywhere extol the praise of God, put away injustice, and promote full security and peace, so far as God should give me strength. ${ }^{46}$

Canute worked closely with Archbishop Ethelnoth of Canterbury but also had a relationship with Archbishop Unwan of Hamburg-Bremen. Under his leadership, the Christian Church in Denmark was organized. Gradually, Canute began to incorporate Christian practices into his government policy. Canute honored saints, began to rebuild monasteries damaged by Viking attacks and outlawed heathen worship. ${ }^{47}$ In 1022, Archbishop Ethelnoth established bishoprics at Roskilde, Odense and the Scanian Islands. ${ }^{48}$ Canute's work in the Anglo-Scandinavian kingdom led to the establishment of many important Churches, particularly st. Edmunds Abbey in England. As a reward for his efforts Canute was invited to attend the coronation of Emperor Conrad II in Rome in 1027. It is a testament to Canute's

\footnotetext{
46 Laurence Marcellus Larson, Canute the Great. (New York: G.P. Putnam's Sons, 1912) page 166.

47 Laurence Marcellus Larson, Canute the Great. (New York: G.P. Putnam's Sons, 1912) page 168.

48 William Bakken, King Cnut and the English Church 1014 to 1035. Chapter VI.
} 
success that even after his death in 1035, Christianity continued to spread throughout the North. ${ }^{49}$

In 1060, Svend Estridsen, Canute's nephew, allowed for a stone church to be built in Dalby for Bishop Egino. ${ }^{50}$ At this time, the church underwent significant re-organization with new bishoprics established in Aarhus, Viborg, Borglum, Ribe, Odense, Roskilde, Vendsyssel, Schleswig, and Lund. ${ }^{51}$ Svend cooperated with Adam of Bremen and lobbied Pope Gregory VII for a separate Scandinavian archdiocese. However, throughout the eleventh century, competition continued between Hamburg-Bremen and Canterbury. Both Germany and England continued to send missionaries to Scandinavia and German influence was particularly strong in Denmark throughout the century.

The power of the Scandinavians was soon to come to an end. In 1066, the Scandinavian loss to the English at Stamford Bridge proved fatal to Harald Haadrada's bid to seize England. Just three weeks later, the Battle of Hastings occurred marking the beginning of Norman dominance under William the Conqueror.

\footnotetext{
${ }^{49}$ Erik Kjersgaard, A History of Denmark. (Copenhagen: Royal Danish Ministry of Foreign Affairs, 1974) page 18.

50 The Church is the oldest remaining stone church on the scandinavian Peninsula.

${ }^{51}$ S. A. Dunham, History of Demark Norway and Sweden. Vol. II (London: 1839) page 179.
} 
In 1073 or 1074, Svend Estridsen died, leaving no legitimate heirs (but at least fifteen illegitimate children). Denmark's throne was contested amongst two of his sons, Harald and Canute the Holy. ${ }^{52}$ With Harald's death in 1080, Canute became king without opposition. In 1080, Canute, a devout Christian, made a donation to the cathedral at Lund thus showing his dedication to the Church. Scania supported Canute the Holy but the Jutes revolted and in 1086 King Canute the Holy was murdered at the altar of St. Allan's church. ${ }^{53}$ His death ended the strength of the Danish crown, an important factor in the victorious Viking expeditions, and the Danish kingdom effectively disintegrated. Canute the Holy was canonized in 1101 and is the patron saint of Denmark. ${ }^{54}$

Despite Canute's death, a school was established at Lund in 1086 and a Church tax was introduced. ${ }^{55}$ In 1104, an independent diocese was established at Lund in the Skane region under Pope Pascal II (1099-1118), who was the principal architect of this foundation. This freed the Scandinavian church from the domination of Hamburg-Bremen.

\footnotetext{
52 S. A. Dunham, History of Demark Norway and Sweden. Vol. II (London: 1839) page 183 .

53 Stewart Oakley, A Short History of Denmark. (New York: Praeger Publishers, 1972) page 45.

54 S. A. Dunham, History of Demark Norway and Sweden. Vol. II (London: 1839) page 187 .

55 Laurence Marcellus Larson, Canute the Great. (New York: G.P. Putnam's Sons, 1912) page 191.
} 
Archbishop Assar of Lund, a member of the Thrugotsen family with royal connections, was subsequently appointed Archbishop and named Primate of Scandinavia. ${ }^{56}$ In 1150 , the Cistercians established their order in Denmark and the other major religious orders were soon to follow. ${ }^{57}$

As Denmark unified, it began to accept Christianity as a way to maintain political power by keeping out foreign powers. Many missionaries worked the area but it was not until the Danish leaders began to accept Christianity that it was accepted throughout. With the acceptance of Christianity, Denmark became a part of the Western Christian world.

\footnotetext{
56 Stewart Oakley, A Short History of Denmark. (New York: Praeger Publishers, 1972) page 47.

57 Laurence Marcellus Larson, Canute the Great. (New York: G.P. Putnam's Sons, 1912) page 169.
} 


\section{CHAPTER 3 \\ CHRISTIANITY - NORWAY'S PATH TO NATIONHOOD}

The conversion of Norway was supported primarily through the work of the Norwegian Kings. During the Viking age, an increase in population and activity with the outside world led to the development of a sense of kinship in Norway. The acceptance of Christianity in Norway was a political move which Norwegian leaders considered necessary in order to become integrated into the western world. English bishops, eager to expand the Christian realm, were instrumental in establishing the Norwegian monarchy and unifying Norway.

In the second half of the ninth century, Harald I Fairhair, an ambitious and energetic Viking chieftain, sought to unite Norway and claimed to be the King of the Norwegians. According to the sagas, Harald Fairhair lived to be eighty years old and had at least nine sons. A clever politician, Harald sought to improve Norway's relationship with England to gain political power. Seeking to befriend King Athelstan, Harold Fairhair sent his youngest son, 
Haakon, to be educated in the King's court in England. ${ }^{1}$ Haakon was raised as a Christian and was very firm in his beliefs. According to Snorri Sturluson, "King Athelstan had Haakon christened and taught him the right faith and good habits and all of kinds of learning and manners." ${ }^{2}$ After Harald's death in 933 his son, Erik, whose mother, Ragnhild, was the daughter of the King of Denmark, ruled in Norway. However, Erik, also referred to as Erik Bloodaxe because of his warrior ways (which included killing several of his brothers), had limited rule, confined mostly to the Southwestern area of Norway. Erik was unpopular and one of his opponents, Sigard, Jarl of Lade, called on Erik's halfbrother Haakon, to return to Norway and rule. Erik soon left Norway to seek his fortune in Northumbria. Erik died in battle in England in $954 .^{3}$

Growing up in Winchester, England, Haakon I or Haakon the Good, began to rule Norway in 935. Haakon the Good, an excellent leader, was Norway's first missionary king who actively spread Christianity. As he acquired power, an

1 Hjalmar H. Boyesen, Norway. (New York: G.P. Putnam's Sons, 1904) Page $72-73$.

However, Boyesen claims this act was actually intended as an insult to the English King in retribution for an earlier incident when the English messengers mocked Harald.

Another theory is that he may have been a hostage, see sawyer page 70 .

${ }^{2}$ Snorri Sturluson. Harold the Fairhaired. Chapter XIIII.

3 Karen Larsen, A History of Norway. ) Princeton: Princeton University Press, 1948) page 88 . 
influx of Christian influences increased in the region. ${ }^{4}$ At this time, Norway increased its diplomatic contact with Christian countries, particularly England. Because of this relationship, English bishops were mostly responsible for spreading Christianity in Norway in the mid-tenth century. The literature and art from this time period increasingly reflected religious themes. ${ }^{5}$ Numerous Celtic objects which have been found in Norway imply a close relationship with Scotland and Ireland - both Christian countries. ${ }^{6}$ In 950, Haakon issued a decree which abolished paganism and sought to spread Christianity throughout Norway. As Snorri Sturluson writes:

It was his intent, as soon as he had set himself fast in the land, and had subjected the whole to his power, to introduce Christianity. He went to work first by enticing to Christianity the men who were dearest to him; and many, out of friendship to him, allowed themselves to be baptized, and some laid aside sacrifices. He dwelt long in the Throndhjem district, for the strength of the country lay there; and when he thought that, by the support of some powerful people there, he could set up Christianity he sent a message to England for a bishop and other teachers; and when they arrived in Norway, Hakon made it known that he would proclaim Christianity over all the land. The people of More and Raumsdal referred the matter to the people of Throndhjem. King Hakon then had several churches consecrated, and put priests into them; and when he came to Throndhjem he summoned the bondes to a

$10 / 3 / 2006$

4 Hjalmar H. Boyesen, Norway. (New York: G.P. Putnam's Sons, 1904) Page 116 .

5 Karen Larsen, A History of Norway. (Princeton: Princeton University Press, 1948) page 89 .

6 Haakon Shetilig, Scandinavian Archeology. (Oxford: The Claredon Press, 1937) 271-272. 
Thing, and invited them to accept Christianity. They gave an answer to the effect that they would defer the matter until the Frosta-thing, at which there would be men from every district of the Throndhjem country, and then they would give their determination upon this difficult matter. ${ }^{7}$

However, advised by a fervent pagan, Sigard, Jarl of Lade, Haakon did not enforce this decree. Obviously, Haakon was uneasy about the Norsemen accepting the new religion and its role in his territory.

Haakon the Good ruled throughout the West and Southwest, and extended to the More lands in the North. However, he came across pagan resistance in Trondelag, which was ruled by Sigard. Soon, Haakon's political power was challenged by the Danes and his nephews, Erik's sons by Gunild, the daughter of King Gorm the old of Denmark. Haakon died in battle in 960. Because his Christian beliefs were not yet accepted, he was given a pagan burial. But Haakon's nephews, also Christians, destroyed pagan temples after his demise. ${ }^{8}$ These actions signify the coming change in the accepted religious beliefs.

Harald Graypelt, son of Erik Bloodaxe, ruled the western area of Norway after Haakon I. Baptized and brought up in the Christian faith, Harald increased his $10 / 3 / 2006$

7 Snorri sturluson. Heimskringla. Chapter VI

${ }^{8}$ Birgit Sawyer, Peter Sawyer, and Ian Wood, editors. The Christianization of Scandinavia. (Alingsas, Sweden: Viktoria Bokforlag, 1987) page 71 . 
power in Norway by killing Jarl Sigard and King Tryggve of the Vigin and Romerik regions. ${ }^{9}$ At this time more Christian missionaries are thought to have entered Norway, although little historical evidence is available. According to Karen Larsen, Harald was the first king to have an established a mission. But due to his oppressive rule, Harald was not a popular king. Harald was killed in 970 after Jarl Haakon, son of Jarl Sigard, and Harald Bluetooth of Denmark aligned and marched against him. ${ }^{10}$

After Harald Graypelt's death, Harald Bluetooth, a Christian, ruled in Eastern Norway, in the Uplands, and in Vik as far as Lindesnes, while Jarl Haakon Sigurdsson ruled the western coastal areas. However, the relationship was troubled; Haakon was a fervent pagan and Bluetooth sought to advance Christianity in Norway. After Bluetooth's death, his successor, Svend Forkbeard, claimed to be king of all of Norway and Denmark but was quickly defeated by Jarl Haakon. After this victory against the Danes, Haakon had many supporters and was considered a hero. ${ }^{11}$ Despite his initial popularity, Haakon's overconfidence eventually led

9 Birgit Sawyer, Peter Sawyer, and Ian wood, editors. The Christianization of Scandinavia.' (Alingsas, Sweden: Viktoria Bokforlag, 1987) page 71.

10 Karen Larsen, A History of Norway. (Princeton: Princeton University Press, 1948) page 92.

11 Karen Larsen, A History of Norway. (Princeton: Princeton University Press, 1948) page 93. 
to his decline. The coastal areas had begun accepting Christianity and Haakon's devotion to pagan beliefs did not help him gain support. After a steady decline in his authority, Haakon was murdered by a slave in Trondelag. ${ }^{12}$ Karen Larsen commemorates Haakon's rule:

Jarl Haakon represented an age that was passing. He was the last chieftain to be an independent ruler without even claiming royal blood; and though he led a purposeful, almost fanatic reaction against Christianity, he was the last genuine heathen to rule Norway. ${ }^{13}$

At this time, an increasing Christian national sentiment in Norway began to emerge.

During the tenth century, through increased interaction with the Danes and the English, Christianity gained support. Sometime around 950, burials with grave goods, a pagan custom, seem to become scarce along the costal districts in southern and western Norway. In addition, there is evidence that a bishop named sigfrid was consecrated in Norway in 975. At this time, though, pagan sentiment still ran strong in the areas away from the coast. ${ }^{14}$

$10 / 3 / 2006$

${ }^{12}$ Snorri Sturluson. Heimskringla. Chapter VX.

${ }^{13}$ Karen Larsen, A History of Norway. (Princeton: Princeton University Press, 1948) page 93.

${ }^{14}$ Birgit Sawyer, Peter Sawyer, and Ian Wood, editors. The Christianization of Scandinavia. (Alingsas, Sweden: viktoria Bokforlag, 1987) page 71-72. 
Christianity made great strides in Norway under the reign of Olaf Tryggvason or Olaf $I$, the great-grandson of Harald Fairhair. Olaf $I$ was the posthumous son of King Tryggve, who was killed by Harald Graypelt. Olaf I was a typical Viking, harsh and cruel but was well traveled. His journeys to Poland, Russia, and England exposed Olaf to the value of Christianity. Olaf was particularly impressed with Kiev, which had recently converted to the orthodox Christian faith.

In 991, Olaf Tryggvason led a Viking expedition to England where he raided the kingdom of Aethelred. He eventually joined with svend Forkbeard and attacked London in 994. While in England, Olaf I continued to terrorize the coast until the English bought peace for 16,000 pounds of silver. To secure the peace, olaf was confirmed in England ${ }^{15}$ by Bishop of Winchester with King Aethelred as his sponsor. ${ }^{16}$ As a condition of peace, Olaf promised not to lead any more Viking raids against England. ${ }^{17}$ olaf I traveled to Norway in about 995 and landed in Moster, on the west coast, where he was recognized as King. It was at $10 / 3 / 2006$

15 Mystery surrounds Olaf's baptism but one theory claims he was baptized by a hermit on the Scilly Island off the Southwest Coast of England, see History of Christianity page 387.

${ }^{16}$ Karen Larsen, A History of Norway. (Princeton: Princeton University Press, 1948) page 94.

${ }^{17}$ C.J.A. Opperman, The English Missionaries in Sweden and Finland. (New York: The Macmillan Company, 1937) page 60. 
this place where olaf built Norway's first Christian church. ${ }^{18}$ A runic inscription in memory of a man, Ulvljot, found on Kuli, a small island near Smola, ends with "twelve winters had Christendom been in Norway." The inscription indicates that Christianity penetrated Norwegian society around 996 or 997. Aslak Liestol claims this inscription is referring to a Thing at Dragseidet where western Norwegians legally accepted Christianity. However, this assertion may be too presumptuous, as the inscription could also be referring to Olaf's introduction of Christianity to the Norwegians in Trondelag, which occurred at about the same time. ${ }^{19}$ The inscription also shows Norway's connection with England as the reference to "Christendom" is of English origin.

The coastal areas of Norway were already familiar with Christianity but Olaf also brought missionaries from England to help convert the entire country. In his attempt to convert the Norwegians, Olaf Tryggvason used force when necessary. As Snorri sturluson noted:

But now that Olaf Trygvason was king of Norway, he remained long during the summer (A.D. 996) in Viken, where many of his relatives and some of his brothers-

$10 / 3 / 2006$

18 Karen Larsen, A History of Norway. (Princeton: Princeton University Press, 1948) page 95.

19 Birgit sawyer, Peter Sawyer, and Ian wood, editors. The Christianization of Scandinavia. (Alingsas, Sweden: Viktoria Bokforlag, 1987) page 73 . 
in-law were settled, and also many who had been great friends of his father; so that he was received with the greatest affection. Olaf called together his mother's brothers, his stepfather Lodin, and his brothers-in-law Thorgeir and Hyrning, to speak with them, and to disclose with the greatest care the business which he desired they themselves should approve of, and support with all their power; namely, the proclaiming Christianity over all his kingdom. He would, he declared, either bring it to this, that all Norway should be Christian, or die. "I shall make you all," said he, "great and mighty men in promoting this work; for I trust to you most, as blood relations or brothers-in-law." All agreed to do what he asked, and to follow him in what he desired. King olaf immediately made it known to the public that he recommended Christianity to all the people in his kingdom, which message was well received and approved of by those who had before given him their promise; and these being the most powerful among the people assembled, the others followed their example, and all the inhabitants of the east part of Viken allowed themselves to be baptized. The king then went to the north part of Viken and invited every man to accept Christianity; and those who opposed him he punished severely, killing some, mutilating others, and driving some into banishment. At length he brought it so far, that all the kingdom which his father King Trvgve had ruled over, and also that of his relation Harald Grenske, accepted of Christianity; and during that summer (A.D. 996) and the following winter (A.D. 997) all Viken was made Christian. ${ }^{20}$

Despite Olaf's enthusiasm, paganism's grip on the inland people remained firm. While the southern and western areas of Norway accepted Christianity, Olaf had problems in Trondelag and in the North where paganism was firmly rooted. According to T.K. Derry, "Only Trondelag and the far north remained recalcitrant, though the heathen

${ }^{20}$ Snorri Sturluson. Heimskringla. Chapter VII. 
temples at Maere and Lade were destroyed by the king in person and the more determined votaries of paganism pitilessly mutilated or put to the sword."21 Olaf's preoccupation with Christianizing the pagan strongholds caused his power in the southern and western areas of his country to wane.

In an attempt to rule Norway, the Dane Svein Forkbeard aligned with Erik and Svein Haakonsson (Jarl Haakon's sons) and Olaf Skotkonug of Sweden. Consequently, Olaf of Norway allied with King Boleslav of Poland. The opposing armies met in battle at svolder in 1000 and olaf was killed. T.K. Derry explained:

In the year 1000, deserted by subjects and allies alike, the first King olaf fought a last desperate battle at svolder, then sprang from his famous flagship, The Long serpent, and disappeared beneath the waters of the Sourd, leaving Norway to another period of Danish (and Swedish) suzerainty, rule by the earls of Lade, and full toleration of pagan rights. ${ }^{22}$

Although olaf had some successes, the Christianization of Norway was not complete upon his death. Although in his short, five-year reign olaf Tryggvason claimed to have converted all of Norway to Christianity most of the conversions were only nominal. However, Olaf's reign helped

$10 / 3 / 2006$

${ }^{21}$ T.K. Derry, A Short History of Norway. (Westport, Connecticut: Greenwood Press, Publishers, 1968) page 40.

22 T.K. Derry, A Short History of Norway. (Westport, Connecticut: Greenwood Press, Publishers, 1968) page 40. 
advance the cause of Christianity in Norway. ${ }^{23}$ Christianity in Norway soon began to serve as a mark of distinction, a statement of independence from pagan Denmark and Sweden.

After Olaf's defeat, his kingdom was ruled by several Viking leaders, including Svein I of Denmark, Olaf Skotkonug, and Jarl Eric and his brother Svein, who were sons of Jarl Haakon. ${ }^{24}$ During this time, paganism was tolerated in Norway but with the victory of the great Viking King, Canute, Christian missionaries gained support in Norway. Canute encouraged the influx of missionaries in the country.

However, it was not until 1015 under the reign of Olaf II Haraldsison that Christianity became completely accepted. A skilled Viking, Olaf II was well-traveled and quite successful in his exploits. According to T.K. Derry,

He is the reputed hero of a famous exploit in which London bridge was broken down by a water-borne attack against its wooden piers, which would make him the only Viking chief to achieve immortality in nursery rhyme. ${ }^{25}$

Olaf II, also a posthumous child and a descendant of Harold Fairhair, worked to define a political structure in Norway

$10 / 3 / 2006$

${ }^{23}$ Karen Larsen, A History of Norway. (Princeton: Princeton University Press, 1948) page 97.

24 Ronald G. Popperwell, Norway. (New York: Praeger Publishers, 1972) page 76 .

${ }^{25}$ T.K. Derry, A Short History of Norway. (Westport, Connecticut: Greenwood Press, Publishers, 1968) page 41. 
and to complete the Christianization of the country. Referred to by his contemporaries as olaf Digre or olaf the Stout, he was baptized and confirmed at Rouen. ${ }^{26}$ Olaf was a passionate advocate of Christianity who organized the Church in Norway by building churches and founding schools. He also brought English missionaries to the country who enjoyed more acceptance than previous missionaries with the strong support of the popular Norwegian Christian King. At this time, more landowners began accepting Christianity. During olaf II's reign, many passionate heathens were converted. In 1024, at a Thing at Moster, the lobbying efforts of Bishop Grimkell, a Norwegian educated in England, and Olaf II, helped establish the first Church of Norway. ${ }^{27}$ A code was established with provisions which included observance of the sacraments and holy days and the prohibition of pagan practices. Snorri sturluson reported, "King olaf had now made the people Christians in all the great districts, and everywhere, by laws, had introduced order into the country." ${ }^{28}$ T.K. Derry also discussed some additional provisions:

But what is most revealing is the attempt to conciliate conservative opinion by keeping up the $10 / 3 / 2006$

${ }^{26}$ T.K. Derry, A Short History of Norway. (Westport, Connecticut: Greenwood Press, Publishers, 1968) page 41.

27 T.K. Derry, A Short History of Norway. (Westport, Connecticut: Greenwood Press, Publishers, 1968) page 42 .

${ }^{28}$ Snorri Sturluson. Heimskringla. Chapter XIV. 
beer-feasts, which had been held in the temples at the end of each of the three annual solemnities. The beer was now to be blessed, and the first toasts were to be drunk 'in honour of Christ and the Blessed Virgin for good years and peace'. ${ }^{29}$

However, Olaf II alienated the chieftains in Upland, where paganism was entrenched. Seeking to end the rule of Olaf II, these leaders called for assistance from King Canute of Denmark. Olaf II fled to Russia in 1028 but he returned upon learning of the death of Earl Haakon, whom Canute had placed in Norway to govern the country. ${ }^{30}$ Olaf II was killed in battle attempting to take back his throne in July 1030. His body was taken to Trondheim and a year later Bishop Grimkell placed his remains above the altar at St. Clements Church. ${ }^{31}$

Canute ascended to the throne after King Olaf's death. An advocate of Christianity, Canute advanced the faith throughout his Scandinavian kingdom. Canute then sent his son, Svein, and his English mother, Queen Aelfgifu, to rule Norway. The outsiders quickly began to offend the independent Norwegians, who soon gained respect for the values for which olaf II died. Within four years the

$10 / 3 / 2006$

${ }_{29}^{2}$ T.K. Derry, A Short History of Norway. (Westport, Connecticut: Greenwood Press, Publishers, 1968) page 42 .

30 Ronald G. Popperwell, Norway. (New York: Praeger Publishers, 1972) page 78 .

31 T.K. Derry, A Short History of Norway. (Westport, Connecticut: Greenwood Press, Publishers, 1968) page 43. 
Norwegians asked Olaf's son Magnus (whose name shows admiration for Charlemagne), who was living in Kiev, to rule their country. ${ }^{32}$ Soon, Christianity became accepted with little opposition as Olaf's passion for Christianity, in the minds of the independent Norwegians, served a mark of distinction against the unruly swedes and encroaching Danes. Thus, Olaf's death strengthened Christianity's grip in the region. This posthumous popularity resulted in olaf becoming a national hero and eventually a saint as numerous accounts of his miracles were reported. ${ }^{33}$ According to Karen Larsen, "By 1030 Christianity had won its duel with the old religion and though the country had by no means become thoroughly Christian, any return to the old faith was out of the question." ${ }^{34}$

With the support of the people of Norway and the bishops, the deceased King Olaf II became st. Olaf on August 3, 1041, the patron saint of Norway and the last western saint accepted in Constantinople. ${ }^{35} \mathrm{~A}$ church was built over his grave at Nidaros is now the Cathedral of

32 Ronald G. Popperwell, Norway. (New York: Praeger Publishers, 1972) page 78 .

33 Karen Larsen, A History of Norway. (Princeton: Princeton University Press, 1948) page 105.

34 Karen Larsen, A History of Norway. (Princeton: Princeton University Press, 1948) page 86.

35 T. K. Derry, A Short History of Norway. (Westport, Connecticut: Greenwood Press, Publishers, 1968) page 43. 
Trondeim. At this time Norway's national sentiment emerged with st. Olaf as its hero. ${ }^{36}$

After St. Olaf, dioceses began to develop in Nidaros (Trondhjem), Bergen, Oslo, and Stavanger. Stavanger's first bishop was an English Benedictine monk from Winchester. Bergen developed into a trading center between Europe and the North. The archbishop in Bremen had little authority in Norway and Rome had very little connection to the newly Christianized country. However, by 1120 Cluniac monks had settled near Trondheim and the Benedictines had three houses, one near modern-day Bergen. Cistercian foundations were established at Lyse (near Bergen) and Havedo (near Oslo). Finally, in 1152, Nicholas Breakspeare, an English cardinal, set up Trondheim as the primary see of Norway with Jon Birgerson as its archbishop. ${ }^{37}$ At this time, Cardinal Nicholas Breakspeare also established the canonical election of bishops with the right to appoint parish priests and establish a tithe. ${ }^{38}$ With the adoption of the tithe, Christianity was officially an accepted religion in Norway.

$10 / 3 / 2006$

${ }^{36}$ Karen Larsen, A History of Norway. (Princeton: Princeton University Press, 1948) page 105.

37 Ronald G. Popperwell, Norway. (New York: Praeger Publishers, 1972) page 82 .

38 T.K. Derry, A Short History of Norway. (Westport, Connecticut: Greenwood Press, Publishers, 1968) page 48, 53-54. 
The conversion of Norway occurred through the work of Norwegian leaders cooperating with outside Christian missionaries ultimately leading to the conversion of the entire kingdom. Through conversion, the Norwegians set themselves apart from the pagan Danes and Swedes. With Christianity, the Norsemen accepted the ecclesiastical organization of the church and soon began to benefit as a state within its own political structures with native political leaders. 
CHAPTER 4

ICELAND: CONVERSION THROUGH LEGAL ACCEPTANCE

In $1000 \mathrm{AD}$, representatives at the Althing, Iceland's parliament, communally agreed through mediation by a single arbiter to formally accept the Christian faith. Icelanders accepted Christianity as a way to unite Icelandic law into a single definite arrangement. Through Christianity, the inhabitants of this barren and isolated island buried their differences and united. The conversion to Christianity acted as an affirmation of the fundamental importance of one nationally agreed upon law. The Icelanders were beginning to cope with a change in the structure of the wealth and power on an island with a scarcity of resources. The acceptance of Christianity was the Icelanders' resolution to maintain the political structure in Iceland, which, as a result, brought changes to the commonwealth. Iceland was transformed both legally and politically into a new, socially stable state. As explained by Margaret Clunies Ross, "Christianity was the religious change Iceland had to have in order to maintain political and 
legal stability at home and to become a full member of medieval European society."1

In the end, Iceland's Commonwealth was a short-lived arrangement, as the rise of the Christian Church and the fall of the Icelandic Commonwealth were closely connected. Iceland's welfare had always been reliant on Norway, and the structure of the Christian church allowed the Norwegians to continue to play a significant role in Icelandic affairs. Eventually, the feuding between the ambitious Icelandic chieftains increased and spread turmoil throughout the country which eventually led the Icelanders to seek peace under the leadership of King Haakon IV of Norway .

The first known inhabitants of Iceland were Irish monks who were seeking an obscure land where it was possible to serve only God. According to Landnamabók:

...Before Iceland was settled from Norway there were other people there, called Papar by the Norwegians. They were Christians and were thought to have come overseas from the west, because people found Irish books, bells, crosiers, and lots of other things... ${ }^{2}$

Little is known about these solitary monks. The first documented settler in Iceland was Ingolfur Arnarson who

1 Margaret Clunies Ross, Old Icelandic Literature and Society. (Cambridge: Cambridge University Press, 2000) page 116-117.

2 Landnamabók: The Book of Settlements. 
landed in Iceland in 874 with his brother-in-law Hjorleif ${ }^{3}$ and eventually settled in Reykjavik. The settlement of Iceland rapidly increased during the tenth century. In the early 900s, discontent with the pagan King Harold Fairhair, who was attempting to establish a Norwegian monarchy under his control and tax its subjects, brought many Norwegians to Iceland. This discontent was discussed in The Laxdoela Saga, which tells a tragic love story and the riches of an influential Icelandic family:

In the latter days of Ketill arose the power of King Harald the Fairhaired, in such a way that no folkland king or other great men could thrive in the land unless he alone ruled what title should be theirs. When Ketill heard that King Harald was minded to put to him the same choice as to other men of might -namely, not only to put up with his kinsmen being left unatoned, but to be made himself a hireling to boot -he calls together a meeting of his kinsmen, and began his speech in this wise: "You all know what dealings there have been between me and King Harald, the which there is no need of setting forth; for a greater need besets us, to wit, to take counsel as to the troubles that now are in store for us. I have true news of King Harald's enmity towards us, and to me it seems that we may abide no trust from that quarter. It seems to me that there are two choices left us, either to fly the land or to be slaughtered each in his own seat. Now, as for me, my will is rather to abide the same death that my kinsmen suffer, but I would not lead you by my wilfulness into so great a trouble, for $I$ know the temper of my kinsmen and friends, that ye would not desert me, even though it would be some trial of manhood to follow me."

${ }^{3}$ Shortly after arriving in Iceland, Hjorleif was taken to the wilderness and killed by his Irish slaves. 
Bjorn, the son of Ketill, answered: "I will make known my wishes at once. I will follow the example of noble men, and fly this land. For I deem myself no greater a man by abiding at home the thralls of King Harald, that they may chase me away from my own possessions, or that else I may have to come by utter death at their hands."

At this there was made a good cheer, and they all thought it was spoken bravely. This counsel then was settled, that they should leave the country, for the sons of Ketill urged it much, and no one spoke against it. Bjorn and Helgi wished to go to Iceland, for they said they had heard many pleasing news thereof. They had been told that there was good land to be had there, and no need to pay money for it; they said there was plenty of whale and salmon and other fishing all the year round there. But Ketill said, "Into that fishing place I shall never come in my old age." So Ketill then told his mind, saying his desire was rather to go west over the sea, for there there was a chance of getting a good livelihood. He knew lands there wide about, for there he had harried far and wide. ${ }^{4}$

This passage shows how Iceland was viewed as a utopia for the independent Norwegians unwilling to submit to anything resembling a royal concentration of power.

The settlers of Iceland were familiar with Christianity. The customs of several early prominent Icelanders reveal this familiarity. Aud the Deep-Minded, the wife of olaf the white and the mother of Thorstein the Red, who settled in Iceland, "used to say prayers at Kross Hills; she had crosses erected there, for she'd been

4 The Laxdoela Saga. Chapter 2. 
baptized and was a devout Christian." ${ }^{5}$ Helgi the Lean was another Icelandic settler familiar with Christianity; "Helgi's faith was very much mixed: he believed in Christ but invoked Thor when it came to voyages and difficult times." ${ }^{6}$ Another Icelander who believed in Christianity was Asolf. "He came to Iceland and made land in the east at Osar. He was a devout Christian and would have nothing to do with the heathen. He wouldn't even accept food from them." ${ }^{7}$

Although the first inhabitants of Iceland were familiar with Christianity, most of them were steadfast pagans. In 930 an independent Iceland was founded based on a non-Christian institution, the Althing. ${ }^{8}$ After organizing as a republic, Icelanders were firm in their independence. However, if any Icelandic foreign policy existed, it was to retain good relations with Norway. In addition, many Icelanders had family ties to Norway, and the country was a source of income for the Icelanders, where many of them traveled for trade and goods.

5 Landnamabók: The Book of Settlements. Chapter 97: Aud Comes to Iceland.

6 Landnamabók: The Book of Settlements. Chapter 218: Helgi the Lean.

7 Landnamabók: The Book of Settlements. Chapter 24: Asolf.

${ }^{8}$ Ulfljot was elected as the first lawspeaker of the Althing and the first Icelandic legal code was known as Ulfljot's code. The Althing met every June on Iceland's Thingvellir plains in the southwestern area of Iceland. The Lesislative body at the Althing was called the Lögretta which consisted of one chieftain from each of the 36 chiefdoms, each with two advisors. 
In 936, Unni, the Archbishop of Hamburg-Bremen, renewed efforts to convert northern Europe. After his brief mission, a slow systematic conversion began. Harold Bluetooth, ruler of Denmark from 940 until 985, organized additional missionary efforts in Norway and Sweden. Haakon the Good (960-990), who ruled Norway after his father, Harold Fairhair, sought to spread Christianity throughout Norway, as did his successor, Harald Graypelt. Although no formal Icelandic missions were organized, these activities were undoubtedly noticed by the Icelanders.

Attempts to convert Iceland were made in the $980 \mathrm{~s}$ but were not successful. In 981, the first missionary to Iceland, Thorvaldr Kodransson Vidforli the Far-Traveled, arrived with his companion, a Saxon cleric named Frederick. ${ }^{9}$ Thorvaldr was a worldly and experienced Viking. He had traveled for some time with Svein Forkbeard ${ }^{10}$ who eventually became the ruler of Denmark. Bishop Frederick baptized Thorvaldr in 981 in Germany. From Vatsdal in northern Iceland, Thorvaldr was the first Icelandic Viking to attempt to convert Icelanders. Thorvaldr baptized many people, particularly members of prominent families, and even built a church in 984 on Thorvardr Spakbodvasson's

9 Frederick is mentioned in Íslendingabók but only briefly: "Frederick came here during the heathendom." The account of Thangbrand and Frederick is mostly discussed in the Kristni saga.

10 Son of Harold Bluetooth and father of Canute 
farm. ${ }^{11}$ Thorvaldr was particularly popular in northern Iceland, his native soil. However, in 985, when Thorvaldr and Frederick presented the new religion at the Althing, the fervent pagan faction would have none of it. His attempt to discuss Christianity was shouted down by the pagans, some of whom retaliated with this Nid:" ${ }^{12}$ "Nine children have been born by the bishop, Thorvaldr fathered them all."13 It was a suggestion that Thorvaldr was a homosexual, a terrible insult during viking times. Thorvaldr proceeded to kill some of the heathens who had lampooned him. The missionaries were subsequently banned and left the island in 986. These missionaries never returned to Iceland.

The missionary efforts to Iceland ceased until 995, when Olaf Tryggvason became king of Norway. Because of the northern Europeans' wavering, the missionary efforts of Olaf I of Norway after he gained power were ruthless. olaf I would not be satisfied until the entire island of Iceland accepted Christianity. However, the clash between

11 Kirsten Hastrup, Culture and History in Medieval Iceland: An anthropological analysis of structure and change. (Oxford: Charendon Press, 1985) page 181.

12 A Norse verbal insult which implies a suggestion of sexual perversion. Lampoons and Nids were popular ways to humiliate enemies in Iceland. Violent retaliation for such insults was common and accepted as a way of defending one's reputation.

13 Kirsten Hastrup, Culture and History in Medieval Iceland: An anthropological analysis of structure and change. (oxford: Charendon Press, 1985) page 181. 
Christians and pagans during these years persisted. The story of Thorkel Moon in Landnamabók: The Book of Settlements represented the struggle between Christianity and paganism which had been developing in Iceland:

When he was lying on his death-bed, Thorkel Moon had himself carried out to a shaft of sunlight, and gave himself to the god who created the sun. He had led a life as blameless as the best of Christians. ${ }^{14}$

This Icelander seems to have valued both pagan and Christian faiths as he was a good Christian but not quite ready to proclaim Christ as the one God who created the sun.

In 995 or 996, Olaf I appointed Stefnir Thorgilson, a Christian Icelander, to aid in the spreading of Christianity throughout Iceland. However, Thorgilson's attempt to convert consisted mostly of destroying heathen temples and idols. As can be expected, Thorgilson was unsuccessful, and his mission achieved little. Thorgilson quickly left Iceland. These unpopular methods of converting the Icelanders resulted in the Althing passing a law in 997 which banned disrespectful treatment of the pagan faith. Obviously religious practice was a matter to be contemplated by the Althing, and this precedent is

14 Landnamabók: The Book of Settlements. 9. Ingolf's Settlement. 
probably important to understanding why Christianity was considered by the secular body in 1000 .

Although Christianity was not the dominant religion by late 995, many Icelanders began to move away from the pagan chieftains and ally with the Christian chiefs. Icelanders were impressed with the Christian faith. Around 999, several prominent Icelanders - Kjartan Olafsson, Haldor, Kolbein, Sverting, Thorarin Nefjulson, Brand the Generous, Thorleik and Hallfredur Ottarsson - befriended King Olaf while visiting Norway and accepted Christianity. Clearly, conversion was becoming fashionable among the influential people of Iceland. ${ }^{15}$

Thorgilson's successor, Thangbrandr, was a Viking who was forced to leave Denmark after committing several murders. After that, he befriended King Olaf, who enticed him to become a priest and oversee the parish on the island of Moster. Thangbrandr was a vicious priest who squandered parish funds and organized raids to replenish them. After Thangbrandr was charged with several burglaries, King Olaf sent him to Iceland, partially as punishment but also as a

\footnotetext{
15 Snorri Sturluson Heimskringla. Of the Icelanders and Baptism of the Icelanders : Wherever they came they were looked upon as people of distinction.
} 
mission for the wily Christian thug. ${ }^{16}$ The saxon priest came to Iceland in 997. Upon his arrival, Thangbrandr lived with Hallr of Sida, a man of great influence in east Iceland. Thangbradr baptized Hallr and his household. Thangbrandr also baptized two Icelandic Chieftains, Gizurr the White Teitsson, and his son-in-law, Hjalti Skeggjason, ${ }^{17}$ sometime during the winter of 998. Thangbrandr quickly worked with Icelandic chieftains and converted many distinguished people in Iceland.

By 999, Iceland was ripe for conversion: Thangbrandr had sowed the seeds of Christianity and the vigor of paganism was fading. Christianity had a substantial hold on society. Many of those baptized by Thangbrandr became ardent supporters of the new religion. With the conversion of the Chieftains, the formal acceptance of Christianity in Iceland was just around the corner. As explained by Sveinbjorn Johnson:

It is likely, however, that Christianity spread extensively among the common people who in this, as in other matters, were likely to follow quite readily in the footsteps of the most prominent chieftains; and it must not be forgotten that the dogma of Christianity carried its strongest appeal to the mind and heart of

16 Snorri Sturluson Heimskringla. Thangbrandr the Priest Goes to Iceland :

When King Olaf Trygvason had been two years king of Norway (A.D. 997), there was a Saxon priest in his house who was called Thangbrand, a passionate, ungovernable man, and a great manslayer; but he was a good scholar, and a clever man.

17 Hjalti was married to Vilborg, Gizurr the White's daughter. 
the common man and found the least resistance in the bosom of the humblest in the social and economic scale. ${ }^{18}$

This is also evident in Njals Saga, when Thangbrandr baptized Gest and those in his household. Thangbrandr spoke of his difficulty at the Althing, and Gest responded, "...Thou hast done most of the work ... though it may be fated that others shall make Christianity law; but it is here as the saying runs, 'No tree falls at the first stroke.'"19 At the Althing in 999, a division between the two parties, the pagans and the Christians, became apparent as a debate ensued. At this time, Hjalti, a recent convert, was banished for his speech at the Althing where he declared, "Barking gods I disesteem, and a bitch I Freya deem."20 Because many Chieftains had accepted baptism and could no longer take heathen oaths, they were forced out of the legal sphere which had been established by the Althing. The number of people considered out of the law was growing. By 1000, the Christian party had successfully organized.

Nevertheless, there were still some in Iceland who were adamantly opposed to the new religion, and

18 Sveinbjorn Johnson, Pioneers of Freedom: An Account of the Icelanders and the Icelandic Free State 874-1262. (Boston: The Stratford Company, 1930) page 196.

$19 \mathrm{Sir}$ George Webbe Dasent, The Story of Burnt $\mathrm{Njal}$. (London: E.P. Dutton \& Co., 1900) page 184 .

20 Islendingabók: The Book of the Icelanders. Chapter VII Of How Christianity Came to Iceland. 
Thangbrandr, who was known for his violent outbursts, was not going to tolerate these problems. When lampooned by two pagans, Thangbrandr reacted with a vengeance: "Thorvald Veile and Veterlide the Skald composed a satire about Thangbrandr; but he killed them both outright." ${ }^{21}$ Thangbrandr returned to Norway in 999, convinced that Iceland would never convert to Christianity. ${ }^{22}$ As explained in Heimskringla by Snorri Sturluson,

The same harvest (A.D. 999) Thangbrandr the priest came back from Iceland to King Olaf, and told the ill success of his journey; namely, that the Icelanders had made lampoons about him; and that some even sought to kill him, and there was little hope of that country ever being made Christian. ${ }^{23}$

Thangbrandr's report of this deplorable behavior enraged King Olaf.

However provocative, Thangbrandr's work in Iceland strengthened Christianity. After the conversion of the powerful Chieftains by Thangbrandr, conversion of the entire island was the next logical step. It was not a total conversion, because paganism was still popular among the masses. When the entire island did not succumb to methods of conversion utilized by the Thangbrandr, Olaf I

${ }^{21}$ Snorri Sturluson. Heimskringla. Thangbrandr the Priest Goes to Iceland

${ }^{22}$ Snorri Sturluson. Heimskringla. Thangbrandr Returns from Iceland

${ }^{23}$ Snorri sturluson. Heimskringla. Thangbrandr Returns from Iceland 
threatened violence and death to all pagan Icelanders in Norway.

Attempting to subdue the efforts of King Olaf, distinguished Icelanders such as Gizurr Teitsson, Hjalti Skeggjason, and Kjartan Olafsson promised King olaf to convert the stubborn pagans in Iceland. As they declared,

King, thou must not fail from thy word -- that however much any man may irritate thee, thou wilt forgive him if he turn from heathenism and become Christian. All the Icelanders here are willing to be baptized; and through them we may find means to bring Christianity into Iceland: for there are many amongst them, sons of considerable people in Iceland, whose friends can advance the cause; but the priest Thangbrand proceeded there as he did here in the court, with violence and manslaughter, and such conduct the people there would not submit to. ${ }^{24}$

The King then baptized all of the Icelanders present. Under the King's orders, Gizurr and Hjalti returned to Iceland determined to Christianize the island. King olaf provided them with a priest, Thormod, and other holy men. To insure that the promise was fulfilled, King Olaf kept four of the chieftans' sons, Kjartan olafson, Haldor Gudmundson, Kolbein Thordson, and Sverting Runolfson, and threatened to kill or maim all of these Icelanders if the mission was not successful. ${ }^{25}$

24 Snorri Sturluson. Heimskringla. Thangbrandr Returns from Iceland

25 Snorri sturluson. Heimskringla. Thangbrandr Returns from Iceland 
The group of Christians arrived in Iceland in June of 999 or 1000 while the Althing was in session. Gizur and some of the Christian party proceeded to the Althing. Because of his speech at the Althing the previous summer, Hjalti was considered an offender and therefore not allowed to visit the Althing. Hjalti made his camp in Laugardal and was joined by eleven other Christian Icelanders. Gizur stopped at Vellankatla near Olfus Lake and sent word to the Christians at the Althing to join his party because the pagans were planning to use force to keep the Christians from attending the Althing. Eventually, Hjalti could not contain himself, and, with his eleven men, also joined the Christian party. The two parties, heathens and Christians, surrounded their leaders. The heated issue of conversion sparked many disputes, and civil war seemed imminent. Both the heathens and the pagans declared the other out of the law. ${ }^{26}$ Gizur and Hjalti then spoke on behalf of the Christians at the Law Rock and made quite an impression. Finally, Hallr of Sida, the lawsayer chosen by the Christians, asked Thorgeir, the pagan lawsayer from the Lake Ljosavatn area in the northern quarter, to settle the dispute. For a whole day and night, Thorgeir lay under his

26 Islendingabók: The Book of the Icelanders. Chapter VII Of How Christianity Came to Iceland. 
pelt and meditated. ${ }^{27}$ After his meditation, he gathered at the Law Rock and spoke of the disputes which had troubled Norway and Denmark and the problems with men not obeying the same law. He also reminded the Icelanders of an old proverb, "If we sunder the law we will also sunder the peace." ${ }^{28}$ Thorgeir then stipulated that Icelanders should formally accept Christianity through baptism since two different systems would destroy the country. According to Icelandic sagas, following this declaration, a mass baptism ensued. ${ }^{29}$

At the Althing it was decided that all Icelanders would accept baptism, but pagan rituals such as eating horse meat, exposing newborns, and performing secret sacrifices to the pagan gods were permitted. Two of the concessions, the eating of horse meat and disposing of infants, were probably allowed for economic reasons. Also, as a conciliation it was decided that sacrifices carried out in public would result in only minor punishment. ${ }^{30}$ Only 125 years after the settlement of Iceland, the Althing, through a great compromise, adopted Christianity in 1000

27 This type of meditation was a common practice for pagans to help decide important matters.

${ }^{28}$ Islendingabók: The Book of the Icelanders. Chapter VII of How Christianity Came to Iceland.

29 Michael Fell, And Some Fell unto Good Soil: A History of Christinatiy in Iceland. (New York: Peter Lang, 1999) page 27.

$30 \mathrm{All}$ of these concessions were rescinded after a few years. 
and averted a civil war between pagans and Christians. It was a conversion in the loosest sense. Christianity became the religion of the state, but individuals were still free to worship their long loved pagan idols. Christianity did not eradicate Icelandic traditions but it did serve as a stimulus for change.

Although the peaceful conversion was a catalyst for change in Iceland, it did not bring great upheaval to former social and political customs; to the contrary, it adjusted to them. Icelandic society simply integrated the roles and demands of the Church into daily life. The differences between the Icelandic and European cultures, coupled with the Icelanders' independent nature, resulted in no real dominance by the Church of Christian Iceland. The island was subjected to the archbishop of HamburgBremen, who was also dealing with the process of conversion in Denmark, Norway and Sweden, and the new church in Iceland suffered from such little support. In addition, the education of the clergymen in Iceland was supplied by foreign bishops from both England and Germany, which initially caused some resentment for the independent Icelanders .

Although the chieftains' role in religion was less direct after conversion, they still retained much control, 
and they reinforced this power in many ways. Some chieftains consolidated their power by serving as priests. As a result, Christian ideals were somewhat represented at the Althing. The Church had influence on Icelandic politics but the chieftains retained dominance over its society. In another attempt to preserve power, chieftains built and maintained Christian churches on their land and were responsible for selecting and compensating the priests. This helped the chieftains in their struggle for power, and it greatly limited any possible political authority of the Church. Many of these priests were treated harshly by the chieftains and lived a life comparable to that of the chieftains' slaves. ${ }^{31}$ These adverse conditions caused Iceland to suffer a shortage of native clergy.

This shortage, however, was countered by the great influence wielded by those bishops that did exist. Olaf Haraldsson, who became King of Norway in 1016, continued to aid the spread of Christianity in Iceland. He persuaded Skapti Thorodsson, the lawsayer in Iceland at the time, to officially ban all heathen practices. In return, olaf Haraldsson sent his court bishop, Bishop Bernhard, a bell

31 William Ian Miller, Bloodtaking and Peacemaking: Feud, Law, and Society in Saga Iceland. (Chicago: The University of Chicago Press, 1990) page 28 . 
and cargoes of timber for churches. Bishop Bernhard was

English. Bishop Rudolf is also believed to have arrived at this time as he is mentioned by Ari and the Hryggjarstykki. ${ }^{32}$ The bishops were sent to oversee the Christian Church in the once pagan country.

The first Icelandic bishop, Isleif, son of Gizurr, was consecrated as bishop around 1056 under Pope Leo IX (104956). Because Bishop Isleif served as both chieftain and bishop, he gained influence in lawmaking. Bishop Isleif's see was located at skalholt, his ancestral estate, in the southwestern part of Iceland. Isleif's knowledge, obtained abroad in Herford in Germany, impressed the Icleandic chieftains who in turn requested he teach their sons. ${ }^{33}$ Thus, Iceland's education system was created and eventually improved because of Christianity.

Isleif was succeeded by his son, Gizurr, in 1082 or 1083, when Gregory VII (1073-85) was Pope. Bishop Gizurr was extremely popular. In 1096 or 1097, Bishop Gizurr and Markus Skeggjason, the lawspeaker, passed the law of tithes

\footnotetext{
32 Knut Gjerset, The History of Iceland. (New York: The Macmillan Co., 1924) page 64 . See also Islandica page $67 \mathrm{Ch}$ VIII of Foreign Bishops

33 Islendingabók. Chapter IX: Of Bishop Isleif. And when chieftains and other good men saw that Isleif was more competent than other clerics who were here at that time, they entrusted to him the educations of their sons and had them ordained as priests.
} 
at the Althing and wrote the law in the Gragas, Iceland's

first law book. As explained by Ari in Íslendingabók:

By reason of his popularity, and because of this and Saemund's representations, and by the counsel of Markus the lawspeaker it was made law that all men should count and appraise their property, and swear that it was correctly valued, whether it was in land or chattels, an then give tithes thereof. ${ }^{34}$

Icelanders were familiar with a system similar to

tithing. Before conversion, they had paid a temple tax to the chieftains. However, with the tithe instituted, the chieftains gained financially due to the distribution of equal quarters to the poor, the bishops, the Church, and the priests, as was customary in Europe. ${ }^{35}$ Because the chieftains owned the churches and were responsible for the payment of priests, they received half of the tithes collected. This helped to further consolidate the chieftains' power.

In 1104, even as Iceland's church was expanding, the Icelandic church came under control of the archbishopric of Lund. In 1106, the second episcopal see was founded in northern Iceland, the bishopric of Holar, with Jon Ogmundarson as its first bishop. With the establishment of the second see, the Icelandic church began to increase its

34 Íslendingabók. Chapter X: Of Bishop Gizur.

${ }^{35}$ However, the Icelandic tithe system was different because it was not based on income; rather, a property tax of one percent of a person's worth was assessed. 
importance in Icelandic politics, as the two bishops had seats on the Lögretta, the legislative body at the Althing. Bishop Gizurr, who made many contributions to Icelandic politics and the Church, died in 1118. Bishop Ogmundarson, who contributed much to the Icelandic church particularly in the North, died in 1121. In 1123 the Church laws compiled by the successors of Gizur and Jon Ogmundarson, Bishop Thorlak Runolfson of Skaholt and Bishop Ketill Thorsteinsson of Holar, were adopted at the Althing. They also commissioned Ari to beging writing his Book of the Icelanders, which preserved much of Iceland's history. ${ }^{36}$

The medieval Church in Iceland greatly worried the leaders in Rome. The peaceful conversion increased Iceland's awareness of the new religion, but Christianity in Iceland suffered because of little external supervision, lack of church funding, and priests who retained formal secular positions. Although Christianity in Iceland was strengthening, the bishops' power was limited, as the church rules were approved by the secular Althing. As late as 1150, the Icelandic clergy were still largely a part of secular society and did not practice celibacy. ${ }^{37}$

\footnotetext{
${ }^{36}$ Gurnar Karlsson, The History of Iceland. (Minneapolis: University of Minnesota Press, 2000) page 29.

37 Gurnar Karlsson, The History of Iceland. (Minneapolis: University of Minnesota Press, 2000) page 42 and 97.
} 
In 1152, an archiepiscopal see was established in Nidaros (Trondhjem) in Norway. At this time, the archbishop of Nidaros, who had jurisdiction over the dioceses of Norway, the Faroes, Greenland, and Iceland, attempted to control Iceland more strictly. Norwegian bishops traveled to Iceland to help with the predicament, but their influence was limited. Until 1238, when two Norwegians filled the bishop's offices in Holar and Skaholt, laymen continued to exercise control over the Church. ${ }^{38}$

In the late twelfth and early thirteenth centuries, Icelandic bishops attempted to bring about more reforms in Iceland. In 1178, Bishop Thorlak Thorhallssonn became bishop of Skalaholt. Supported by the archbishop in Nidaros, Eysteinn Erlendsson, he attempted reforms to limits the Chieftains' role in the church. In 1190, Norwegian Archbishop Erikir Ivarsson established a law stating that chieftains could no longer be ordained unless they abdicated their titles. This was an extremely unpopular measure, and upon Bishop Thorlak's death in 1193, most of these reforms were abandoned. Bishop Guthmund Arason of Holar, with support of the archbishop in Nidaros,

\footnotetext{
${ }^{38}$ Gurnar Karlsson, The History of Iceland. (Minneapolis: University of Minnesota Press, 2000) page 43 .
} 
also tried to reform the Church. He was largely unsuccessful. However, the relationships that had developed between the Icelandic bishops and the archiepiscopal see in Nidaros reinforced the bonds between Iceland and Norway. As earlier stated, after the deaths of Bishop Guthmund of Holar and Bishop Magnus Gizurarson of Skalaholt, two Norwegians were appointed as bishops in Holar and Skalaholt. Gradually, the bonds strengthened to the point that the Church's hierarchy allowed Norwegian kings to intervene in Icelandic affairs.

The conversion to Christianity allowed for transformations in Iceland's social and political arena. Yet the legal acceptance of Christianity progressively destabilized secular authority in Iceland. Politically, after conversion, Iceland still suffered from power struggles and family feuds. Christianity worked to dilute the old political order, and, eventually, as the church sought foreign support in its struggle with secular powers, the power ceased. King Haakon IV of Norway exploited the internal squabbles of Icelandic politicians, and Icelanders soon recognized him as their king. In 1262, many Icelanders, searching for a solution to the feuding chieftains, allied with King Haakon IV, who promised peace. 
By 1264, Iceland was officially subject to the crown of Norway .

The acceptance of Christianity in Iceland left its mark on Icelandic society, as it had much cultural influence. Conversion brought European progress to Iceland, introduced the Roman alphabet to the island, established schools, and advanced Iiterature. After Iceland's conversion many priests were treated as slaves of the chieftains, but the implementation of the Christian education system preserved the history and literature of Iceland. The Christian priests taught the chieftains' sons to write in the Icelandic language. Because of this, many of them went on to record the history of Iceland in sagas, skaldic poetry, and eddas. Thus, literary creativity flourished in Iceland after conversion. These writings preserved the poetic forms of the past and enhanced the development of the Icelandic saga. Because Icelanders knew how to read and write, conversion preserved the Icelandic language and literature, which adapted to the preaching of the new faith. Hence, Christianity helped to preserve and stimulate Icelandic history, language, and literature.

Iceland adopted Christianity as a state religion in 1000 by parliamentary decree. Although Christianity helped develop the commonwealth, because of the power struggles 
within the social structure and political system of Iceland, the organization of the Christian Church ultimately contributed to the decline of the Icelandic Commonwealth. However, the effects Christianity had on Icelandic literature and history are invaluable. Christianity brought trade, travel, communication, ideas, and education, and conversion aided Iceland's integration into European culture. According to Gjerset:

A new day was to dawn through the coming of Christianity; new opportunities for intellectual and social progress were created through the closer connections with all Christian nations established by the church; but the leaven of the Christian faith had to work for centuries before the pagan mind of Iceland yielded fully to its spiritualizing and ennobling influence. ${ }^{39}$

${ }^{39}$ Knut Gjerset, The History of Iceland. (New York: The Macmillan Co., 1924) page 70. 
CHAPTER 5

SWEDEN: CONVERSION THROUGH INDIVIDUAL ACCEPTANCE

Compared to other Scandinavian countries, Sweden was slow to convert. The first missionaries to sweden in the ninth century were forgotten long before Christianity was formally accepted approximately two-hundred and fifty years later. Although Christianity was allowed into Sweden for political reasons, the first missionaries to enter sweden came because of spiritual guidance and absolute devotion to the Church. Ultimately, Sweden's conversion to Christianity was politically motivated as Swedish internal conflict tormented its ruling class, who sought Christianity as a way to establish a polity with its own leaders in power.

In 827, King Bjorn of Sweden feared an assault from King Horik of Denmark. Realizing the political advantage of allying with the Franks, King Bjorn sought the aid of Louis the Pious and invited Louis to send a Christian mission to Sweden. As he was eager to spread Christianity, Louis requested that the Frankish monk, Anskar, lead the 
mission. Determined to continue his missionary work in the North, Anskar happily obliged. ${ }^{1}$

In 830, Anskar traveled with the monk witmar to Sweden. The mission was attacked en route to Sweden and Anskar lost many valuable items, including many religious books, sent to King Bjorn from King Louis. However, Anskar was not discouraged and continued his journey until he reached Birka, on Lake Marlaren near present day Stockholm. Upon his arrival in Birka, King Bjorn welcomed Anskar. Disregarding King Bjorn's political motives, Anskar and Witmar zealously attempted to Christianize Sweden. King Bjorn allowed Anskar to build a church in Birka. ${ }^{2}$ Anskar was successful in baptizing Herigar, the Governor of Birka, who subsequently worked in the mission for many years. Having founded the mission, Anskar and witmar returned home in 831. Simon-Gautbert, nephew of Ebbo (the first papal legate to the North), replaced Anskar to carry out the missionary work. In 839, the mission at Birka was destroyed during an anti-Christian riot and simon-Gautbert fled, while his nephew and chaplain, Nithard, and other Christians were martyred. ${ }^{3}$

1 Rimbert. Vita Ansgarii Chapter IX.

2 Irene Scobbie, Sweden. (New York: Praeger Publishers, 1972) page 22.

3 Adam of Bremen, History of The Archbishops of Hamburg-Bremen by Adam of Bremen. Francis J Tschan, translator. (New York: Columbia University Press, 1959) Page 26-27. 
After the Viking attack of Hamburg in 845, Birka's missionary activities fell into ruin, as they did in the rest of the North. Herigar, the Birka governor Christianized by Anskar, died in late 851 leaving no real champion of the religion in the country. A priest named Ardgar arrived in Birka in 851 and attempted to resume missionary activity. Also at the time, as a result of the problems with Christianizing the North, Hamburg and Bremen were joined through a Papal Bull issed by Pope Nicholas I. In Birka, persecution of Christians continued and Ardgar soon abandoned the mission, seeking a more solitary religious life. Anskar returned to Sweden in 852 , where his former missionary work was in disarray. King Olaf was now ruling the country. Anskar did not have as cordial relationship with olaf as he enjoyed with King Bjorn. According to Rimbert, the superstitious Swedish king allowed Anskar to continue his mission after he consulted with other leaders and cast lots. ${ }^{5}$ Anskar's high status among the rulers in Denmark and Germany probably also made an impression on the new king. In addition, Anskar provided King Olaf with many gifts. With renewed royal

${ }^{5}$ Rimbert. Vita Ansgarii. Ch 24. 
support, the mission gained ground and Anskar was eventually able to build new churches.

Once he felt his work had a firm foundation in Birka, Anskar once again returned to Bremen. Upon his departure, Anskar appointed Erimbert, a nephew of Simon-Gautbert, to head the mission. Anskar continued to provide Sweden with support as he sent three missionaries to Sweden: a Danish priest named Ansfrid, who returned to Hamburg-Bremen on the death of Simon-Gautbert; Raginbert, who was murdered by Danish Vikings before reaching Sweden; and Rimbert, a missionary who shared Anskar's biographer's name. ${ }^{6}$ Anskar died in 865. According to C.J.A. Oppermann:

And so between the time of the death of Anskar and the later years of the reign of Erik Segersall, the father of Olov skotkonung, the first Christian king, we not only know little of the general history of Sweden, but even less about the Christian Church there. Now and again shadowy figures - at one time a king, at another time a bishop - emerge for a brief space of time from the general obscurity, but the chronology of the period is terribly confused, and it is not always easy to say how much there is of truth in the few accounts that have come down to us of the events of these times. 7

Anskar's friend, biographer, and fellow Frank, Rimbert, was appointed in a Papal Bull by Pope Nicholas I

\footnotetext{
6 Rimbert. Vita Ansgarii. Ch 28.

7 C.J.A. Opperman, page 47.
} 
to continue work in Birka. ${ }^{8}$ Adrian II appointed Rimbert

legate of the North a few years later. However, Rimbert could not increase interest in the North. After Rimbert's death in 888, these efforts came to an end and Sweden once again abandoned the faith. Aldagar succeeded Rimbert as Archbishop but it is unclear if he traveled to Sweden. If his successors Hoger and Reginwald attempted to Christianize Sweden, it is not documented. ${ }^{9}$

According to Widukind's Res gestae Saxonicae, the Swedish King Gnupa was defeated at Hedeby in 934 and was forcibly baptized by the German Emperor Henry I. ${ }^{10}$ In 936, Unnili, a former monk of Corbie and successor of Anskar as

\footnotetext{
${ }^{8}$ Adam of Bremen, History of The Archbishops of Hamburg-Bremen by Adam of Bremen. Francis J. Tschan, translator. (New York: Columbia University Press, 1959) Page 30.

9 C.J.A. Opperman, page 47.

10 Widukind's "Res gestae Saxonicae", Book 1, section 40 (part): Latin text (from PL 137: 156): (DCCCCXXXIV) Cum autem omnes in circuitu nationes subjecisset, Danos, qui navali latrocinio Fresones incursabant, cum exercitu adit vicitque, et tributarios faciens, regem eorum nomine Chnubam baptismum percipere fecit. English translation by Storm [Storm 335]: (934) [Henry the Fowler,] after having subdued all nations around him, attacked the Danes, who had harried the Frisians from the sea, and he subdued them, and made them pay taxes, and compelled their king, Gnupa, to be baptized.
}

11 Adam of Bremen also talked about Unni but not much information is provided. Adam of Bremen claimed Unni reconverted the Svear and Gotar. Obviously, Unni revived the mission but his intentions are unclear, Unni may have sought to reintroduce the Swedes to Christianity or simply sought to assert Church authority in Sweden. 
archbishop of Hamburg-Bremen, traveled to Birka. ${ }^{12}$ Unni was preparing to return to Germany when he died in Birka on September 17, 936. ${ }^{13}$ Although Unni was successful in rejuvenating the missions in Birka and making a few converts, his influence did not extend far and much of Sweden remained pagan. Unni's activity in the North was limited, but his mission marked the revival of missionary work in the North. The presence of the Church and priests, as well as Christian merchants, contributed to the later acceptance of Christianity. Unni's successor Adaldag continued to pursue the North as directed by a Papal Bull issued on January 2, 948 from Pope Agapetus II. Adaldag sent a Dane, Odinkar, to Sweden, and another Danish bishop, Liafdag of Rippa also served in Sweden. ${ }^{14}$ Adaldag died in 988 and was succeeded by Libentus.

In Sweden, internal disorder and wars endangered the missions that Anskar had founded. In addition, Birka's position was declining, and it stopped being a trading center before the end of the tenth century. Regardless of the political disputes, in the late tenth century bishops are known to have been active in Sweden. By the beginning

${ }^{12}$ Adam of Bremen, History of The Archbishops of Hamburg-Bremen by Adam of Bremen. Francis J. Tschan, translator. (New York: Columbia University Press, 1959) Ch 63.

13 Franklin D. Scott, Sweden: The Nation's History. (Minneapolis: University of Minnesota Press, 1977) Page 35.

14 Adam of Bremen Vol II, Ch 23. 
of the eleventh century, Norway and Denmark were Christianized and began sending missionaries to Sweden. Missionaries from Germany and England also entered Sweden and competed with one another to convert the North. ${ }^{15}$ Missionaries also came from France and the Eastern Orthodox Church in Russia. ${ }^{16}$

Saint Sigfried is the best known of English missionaries in Sweden, although his missionary activity was confined to Vastergotland and Smaland in southern Sweden. Sigfried was the Archbishop of York. According to Icelandic tradition, sigfried worked in Sweden after being commissioned by olaf Tryggvason, who had married his sister to Ragnwald Ulfsson, Jarl of Vastergotland, on the condition that his subjects accept Christianity. To aid their conversion Olaf sent missionaries to Vastergotland who probably included Sigfried. ${ }^{17}$ The account of Sigfried's life does not mention his relationship with olaf Tryggvason. However, it is known that King Olaf of Sweden requested from King Mildred of England that missionaries be

\footnotetext{
15 Byron J. Nordstrom, The History of Sweden. (London: Greenwood Press, 2002) page 34. see also Franklin D. Scott, Sweden: The Nation's History. (Minneapolis: University of Minnesota Press, 1977) Page 36.

16 Irene Scobbie, Sweden. (New York: Praeger Publishers, 1972) page 22 .

17 C.J.A. Opperman page 63, Heimskringla OTS 105, 106
} 
sent and Sigfried happily offered to lead the mission. ${ }^{18}$ Sigfried made Vaxio the center of his missionary activities and traveled around Sweden to convert. Sigfried converted twelve representatives of the Chief tribes in Sweden. King Olaf Skotkonung of Sweden (990-1022) heard of these activities and requested that sigfried meet with him, which Sigfried did while Christianizing swedes along the way. ${ }^{19}$ Olaf Skotkonung became the first Christian king of Sweden when he was baptized at Husaby by Saint Sigfried. ${ }^{20}$ Sigfried is said to have built the first church at Vaxio. Sigfried died some time between 1060 and 1070. Sigfried was canonized by Pope Adrian IV in 1158 and is commemorated on February $15^{\text {th }} \cdot{ }^{21}$

Aelnoth, a bishop from Canterbury and a writer in the twelfth century, claims the English Bishop Eskil labored in Sodermanland just south of Uppsala, and suffered the death of a martyr when he appeared at a Thing and preached against heathen sacrifices. He was buried at Tuna - now known as Eskiltuna. ${ }^{22}$ Eskil's successor, Botvid, was not English, but was baptized in England and taught the Christian faith in Sodermanland. He was killed by a

18 C.J.A. Opperman page 67

19 C.J.A. Opperman page 67-70.

20 C.J.A. Opperman page 75.

21 C.J.A. Opperman page 90.

22 Irene Scobbie, Sweden. (New York: Praeger Publishers, 1972) page 23. 
Wendish slave he was attempting to convert. ${ }^{23}$ Saint David was said to be a monk of the Cluniac order who came to Sweden sometime after 1020, preaching in the southern part but then also reaching Vastmanland near Uppsala. Other English missionaries who worked with the swedes included Gotebald, about whom little is known; Grimkel, nephew of Sigfried and King Olaf's court bishop; Bishop Rudolf of Nidaros; Bernard who also worked in Norway and Iceland with King Canute; and Woldred, who was killed for having destroyed a pagan image of Thor during a sermon, thus showing this tactic was not going to work in sweden. Saint Stephen is also mentioned in Swedish history and is said to have preached in the northern part of Sweden. The persistence and presence of this many missionaries ultimately led to the success of Christianizing Sweden. ${ }^{24}$

In the eleventh century, Christian inscriptions on runic stones prove that upper-class Swedes were Christian and willing to show their faith openly. ${ }^{25}$ The existence of such artifacts indicate that some sort of strong Church organization existed and kept Christianity around everyday society. However, despite Christianity's achievements, further North and West paganism still flourished.

23 C.J.A. Opperman page 117

24 C.J.A. Opperman. page 87-94.

25 Irene Scobbie, Sweden. (New York: Praeger Publishers, 1972) page 23. see also Sawyer page 74 . 
During Olaf Skotkonung's rule from 990-1022, the first bishopric was established at Skara in Vastergotland under the authority of Hamburg-Bremen with Thurgot as its bishop. ${ }^{26}$ According to Adam of Bremen, Olaf rigorously converted Sweden and attempted to destroy the pagan temple at Uppsala. ${ }^{27}$ However, Olaf's efforts to impose Christianity were frustrated by the stubborn pagan swedish chieftains. Olaf's zeal was ultimately restrained by a decision of his subjects at a Thing. Although the Thing permitted olaf to build churches and allow the worship of Christianity to continue, he was prohibited from forcing a new religion on anyone. ${ }^{28}$

The successors to the king, Olaf's son Anund Jakob, Anund's half brother Edmund, and Stenkil (Edmund's newphew), were all Christians. ${ }^{29}$ Anund Jacob was a popular ruler who was friendly with Olaf of Norway, but he died in 1052 and was succeeded by Emund. King Emund allowed Osmund, nephew of Sigfried, to act as court-bishop, and this freed Sweden from the see of Bremen. ${ }^{30}$ However, this rejection of Hamburg Bremen's ecclesiastical authority in Sweden upset Archbishop Adalbert, who responded by

\footnotetext{
${ }^{26}$ Irene Scobbie, Sweden. (New York: Praeger Publishers, 1972) page 23.

27 Adam of Bremen Vol II Ch. 56.

${ }^{28}$ C.J.A. Opperman. page 84 .

${ }^{29}$ C.J.A. Opperman. page 86.

30 C.J.A. Opperman. page 99
} 
appointing Adalvard, Dean of Bremen, Bishop for the Swedes and sending him to Sweden. ${ }^{31}$ After a meeting of the Thing, Adalvard was sent away, but after a period of draught and famine, the Swedes soon recalled Adalvard. With this, Osmund made good with Archbishop Adalbert who allowed him to work in Skara and Hallard. ${ }^{32}$

During Stenkil's rule a bishopric was founded by Bishop Adalward at Sigtuna, near Uppsala, paganism's stronghold. ${ }^{33}$ Sigtuna became the center of the Christian faith in the Malar district. In Vastergotland in southwest Sweden, Christianity, introduced mainly by English missionaries, then organized by German missionaries from Hamburg-Breman, became accepted. However, in other areas of Sweden, particularly Uppland or Svitland, Christianity did not take hold. ${ }^{34}$ In the central areas of Sweden paganism flourished and the old religion held firm in the Svear tribe. Pagans drove out the bishops of Sigtuna in 1066 and in 1075 Skara was also without a bishop. Aelnoth, the Anglo-Danish monk from Canterbury, noted in the early twelfth century that the pagans would accept Christianity if things went well, but when problems occurred, they

31 Adam of Bremen, Vol. III Ch 14.

32 C.J.A. Opperman, page 100-101.

33 Irene Scobbie, Sweden. (New York: Praeger Publishers, 1972) page 22 .

34 Franklin D. Scott, Sweden: The Nation's History. (Minneapolis: University of Minnesota Press, 1977) Page 39. 
persecuted Christians and destroyed missions. ${ }^{35}$ Adam of Bremen also documented the problems with the Swedes converting. ${ }^{36}$

Inge the Elder, son of Stenkil, became king around 1080 and was active in the Christian faith as evidenced by Pope Gregory VII's letters to him. Inge did away with sacrifices at Uppsala and attempted to destroy the pagan temple. Despite Rome's support and Inge's enthusiasm, an anti-Christian uprising continued and the Christian king was banished by the Svear for refusing to perform pagan rites, a role many in the tribe regarded as part of his duty. ${ }^{37}$ During this time, Eskil was martyred. Inge stayed in Vastergotland while his brother, Blot-Sven, who would perform sacrifices, ruled for three years. However, Inge returned to destroy the pagan temple at Uppsala and built a Christian church in its place. Inge's reign signified the increasing acceptance of Christianity in Sweden. The temple at Uppsala had provided a stronghold for pagan resistance and once it was destroyed Christianity made great headway in the pagan area.

In 1104, the Swedish Church passed from the control of Hamburg-Bremen to Lund, at that time a part of Denmark.

35 Franklin D. Scott, Page 39.

${ }^{36}$ Adam of Bremen. Book 4 page 192.

37 Irene Scobbie, Sweden. (New York: Praeger Publishers, 1972) page 23. 
Archbishop Assar was appointed Archbishop of Lund and primate of Scandinavia. ${ }^{38}$ Through the missionaries' zealous preaching, care for the sick and poor, education, and celebration of Christian holidays, the Christian faith eventually took hold. In 1152, an Englishman, Nicholas Breakspeare, visited Sweden as a Papal Legate to establish an archbishopric. However, the Svear and Gotah tribes could not agree on a location, so it remained at Lund. Eventually, to show Christianity's victory over paganism, the archbishopric was established at Uppsala. In 1130 Uppsala replaced Sigtuna as the episcopal seat and became the metropolitan see of Sweden in 1164 with Cistercian as its first Bishop. Bishoprics continued to develop and by the thirteenth century, existed in Linkoping, skara, Strangnas, Vasteras, Vaxjo, and Abo (in Finland). ${ }^{39}$ The first bishop of Sigtuna was Adalward the Younger. ${ }^{40}$

Many missionaries put forth great efforts to promote the conversion of the superstitious Swedes. Conversion in this scandinavian country occurred only after many years of missionary activity which was advanced once the leaders began to embrace the new religion. Once Swedish leaders

\footnotetext{
38 Irene Scobbie, Sweden. (New York: Praeger Publishers, 1972) page 23.

39 Byron J. Nordstrom, The History of Sweden. (London: Greenwood Press, 2002) page 34 .

40 C.J.A. Opperman, page 120.
} 
realized encroaching outside Christian forces were threatening Sweden's internal power structure, they began to accept the faith as a way to maintain their political power. Ultimately, the Swedes converted to combat the political influences coming from Western European nations. 
CHAPTER 6

CHRISTIANITY: FINLAND'S ENTRY TO THE CHRISTIAN WORLD

For centuries the Finns existed in a state of isolation on the peripheries of both Eastern and Western Christendom. After 1000, however, as the Finns gradually became more aware of the outside world, they began to embrace Christianity, the dominant religion of Europe. Christianity led the Finns to develop a new conception of the world. As their worldview changed their religion so too did this new religion change their worldview.

Finland is a very secluded territory in northern Europe with many remote areas surrounded by woodlands. The culture has always been influenced from both the East and West. The Finnish language is of Ugric origin but the Finns were active traders with the west. The Finns had no central leader with the social structure based on powerful families and clans. Little is known about the Finns' religion before Christianity began creeping into the territory. Thought to be more superstitious than their neighbors the Swedes, the Finns apparently worshiped 
spirits which were assigned to a particular object. Ukko appears to be a main deity but his importance is only noted after the Finns were familiar with Christianity. ${ }^{1}$

It is unclear how, when and where Christianity entered Finland. Christianity entered through many different contacts but little is known of its earliest entry. Tuomas M. S. Lehtonen explains:

The arrival of the written culture and power associated with church and state cannot be dated with certainty before the second half of the twelfth century, and it was only in the thirteenth century that these institutions became securely established, marking the assimilation of Finland into Western Latin Christianity. ${ }^{2}$

Although much of the history of Finland's conversion is vague, each version sheds some light on the nebulous topic. Christianity in Finland was influenced by both orthodox Christianity from the East and by Roman Christianity from the West. Although Christian missions ultimately helped to convert the Finns, they did not directly result in the acceptance of the religion. The Christianization of Finland was a long process of contacts with the outside world. Christianity entered Finland through many trade and cultural contacts dating back to the eighth century.

\footnotetext{
${ }^{1}$ Paula Purhonen, Kristinuskon Saapumisesta Suomeen. "On the Arrival of Christianity in Finland: A study in the archaeology of religion" (Helsinki: 1998) page 189.
} 
However, Christianity was ultimately adopted after the organized Christian missions of the twelfth century set their sights on Finland. Therefore, both schools of thought tell different aspects of the true story of how Christianity first arrived in the country.

Although many historical sources talk about Finlands' acceptance of the new religion starting in the mid-twelfth century, when organized Christian missions first entered Finland, archeological evidence supports the theory that Christianity reached Finland before the end of the first millennium. Archaeological finds dating to around the year 800 exhibit Christian motifs such as a crucifix or a cross pendant, and indicate the Finns' familiarity with and use of Christian symbols. ${ }^{3}$ In Fred Singleton's book, A Short History of Finland, he refers to, "A runic inscription in Sweden, dated from the early eleventh century, [which] refers to a Swedish crusader who died in Tavastland (Hame).${ }^{4} \quad$ The discovery of these traditional Christian emblems and icons suggest that the Finns were familiar with Christianity before the twelfth century.

\footnotetext{
2 Tuomas M. S. Lehtonen, Europe's Northern Frontier. (P.S. Kustannus: Jybaskyla, Finland: 1999).

3 Paula Purhonen, Kristinuskon Saapumisesta Suomeen. "On the Arrival of Christianity in Finland: A study in the archaeology of religion" (Helsinki: 1998) page 189.

4 Fred Singleton, A Short History of Finland. (Cambridge: The Cambridge University Press, 1998) Page 16.
} 
The burial customs of the Finns also provide evidence of early Christian influence in Finland. Although cremation of the dead was a popular pagan burial method, evidence of inhumation burials, discovered in lower satakunta, may date back to the end of the sixth century. It is apparent that the custom also spread to Ylane, at the southern end of Lake Pyhajarvi in inner Finland proper. However, it was not until the eleventh century when the pagan cremation decreased dramatically and inhumation burials in cemeteries became the custom. Many graves dating back to the mideleventh century in southwest Finland exhibit Christian burial characteristics, which include the placement of the deceased on his or her back in a wooden coffin with his or her arms crossed over the chest. ${ }^{5}$ The widespread adoption of Christian burials, while possibly dating back to the late sixth century, were slow to take hold in Finland. Despite the almost total abandonment of cremation burials, offerings with burials continued for some time in Finland. As late as the thirteenth century, Finns were still burying goods with the dead, another pagan burial custom of the time. As this pattern indicates, while the Finns were familiar with Christian burial techniques, they still held

\footnotetext{
5 Paula Purhonen, Kristinuskon Saapumisesta Suomeen. page 190.
} 
on to their pagan practices. ${ }^{6}$ Regardless, the graves are further evidence that the Finns at least knew of and were influenced by Christianity, even if they had not actually accepted the religion on a whole.

It appears that the Finns became aware of Christianity through trade and cultural contacts with Sweden, Russia, and the Baltic states. The Finns are certain to have encountered Christianity while venturing to other lands. ${ }^{7}$ In addition to the Finns' expeditions, it seems that there was contact between Finnish and Swedish fur traders. Finns regularly traveled the Austvegr, a common trade route for the Northern Europeans. ${ }^{8}$ They were bound to have encountered Christianity while conducting business with other merchants during these travels. Novgorod, a Viking establishment with links to Kiev and an important Russian trading town, had strong influence in Karelia, in eastern Finland. Novgorod's influence possibly extended even further west. Kiev adopted Christianity in 988 and Novgorod founded its bishopric soon after; the Finns were certainly familiar with Eastern Orthodox Christianity

\footnotetext{
${ }^{6}$ Birgit Sawyer, ed. The Christianization of Scandinavia. (Viktoria Bokforlag, 1987) page 34 .

7 According to the Primary Chronicle of Yaroslav (Iaroslav) the Wise, ruler of Russia after Prince vladimir of Kiev's death, the Finns were often fighting with the Russians. According to most historians, the Finns were also notorious for bothering the inhabitants of Sweden.
} 
because of contacts with the East. In addition, because of the similarities between the languages and cultures, the Finns probably also had contact with the Baltic region, particularly Estonia, where they may have come across some aspects of the new religion.

Because of the aggressive nature of the Finns and their cultural activities it seems certain that the Finns knew about Christianity. However, historical proof of the extent of the Finns' knowledge does not exist. One may hypothesize as to the extent of Christian influence in Finland through cultural contacts before the twelfth century. As C.J.A. Oppermann explained his view on Christianity in Finland before the mid-twelfth century:

It is possible that there may have been some Finns associated with the Swedish traders using the Austvegr in Viking times, and that they may have come in touch with Christian merchants from other lands; the Finns in the course of their piratical expeditions may have captured some Christian slaves and from them have learnt something of the doctrines of Christianity; or again, the Swedish conquests in Finland in the time of Erik Segersall may have introduced the inhabitants of the country to a form of Teutonic heathenism that had already had its beliefs modified to a limited extent by Christian influences. We know that Finnish heathenism shows decided traces of having incorporated ideas that were probably borrowed from the dwellers in the land, and it may thus have acquired at second-hand the first faint traces of Christian ideas. ${ }^{9}$

\footnotetext{
${ }^{8}$ C.J.A. Oppermann, The English Missionaries in Sweden and Finland. (New York: The Macmillan Company, 1937) page 27.
} 
The Christianization of Finland may have been greatly influenced by the West, but Christian contacts with Finland started from the East. The use of Slavic words, basic Christian symbols and beliefs such as the words for cross, priest, heathen, bible and godparent (risti, pappi, pakana, raamattu and kummi) in the Finnish language indicate that early Christian contact came from the East. ${ }^{10}$ In addition, a Papinsaari hoard from Kuhmoinen contains many pieces decorated with Christian symbols which show the existence of some influence from the East. ${ }^{11}$ However, little focus is given to the missionaries from the east until Yaroslav Vassievolodovich (Iaroslav Vsevolodovich) became Grand Duke of Novgorod in the thirteenth century. Because Finnish words relating to basic concepts within Christianity are of Slavic origin, and some of the earliest artifacts show influence from the Eastern Church, it can be inferred that the first Christian influences in Finland came from the East. Thus, the theory that the East provided Finland with its first Christianity is rooted in cultural indications.

\footnotetext{
9 C.J.A. Oppermann, The English Missionaries in Sweden and Finland. (New York: The Macmillan Company, 1937) page 27

10 Paula Purhonen, Kristinuskon Saapumisesta Suomeen. "On the Arrival of Christianity in Finland: A study in the archaeology of religion" (Helsinki: 1998) page 186 and 189.

11 Paula Purhonen, page 189.
} 
Although it has been established that the Finns had contact with Christianity before the twelfth century, the first noted organized missionaries arrived in Finland in the mid-twelfth century from Sweden. The papal legate, Cardinal Nicholas Breakspeare, is said to have been a significant figure in extending Christianity to Finland, but historians disagree as to the amount of influence he asserted. Some claim he was directly responsible for the first mission to Finland, vigorously encouraging King Erik of Sweden and Bishop Henry of Uppsala to attempt to tame and convert the unruly Finns. ${ }^{12}$ others believe he merely consecrated St. Henry as bishop of Uppsala and instructed him to spread Christianity, thus indirectly implying the need to convert Finland. With this role, Bishop Henry was supposedly influential in convincing King Erik to go to Finland. ${ }^{13}$ Other historians believe that King Erik was simply influenced by Nicholas Breakspeare when he took his oath to become king and promised to fight for Christianity and against enemies of his kingdom, thereby obliging him to fight against Finland and Christianize the heathen state. Then again, King Erik may not have been as important as some historians allege. It has been claimed that $s t$. Henry's mission to Finland in the mid-twelfth century was

${ }^{12}$ C.J.A. Oppermann, page 173 and 199. 
first connected with King Erik some 150 years later, at the end of the thirteenth century, in order to legitimize the authority of his heirs. ${ }^{14}$

In the story of the Christianization of Finland, st. Henry is known as the Apostle of Finland, a bishop who came to Finland to baptize and preach the Christian word. However, some modern Finnish historians question if this first crusade ever actually occurred. ${ }^{15}$ As there is no historical proof of St. Henry's existence, this claim cannot be ignored. The story of st. Henry as the Apostle of Finland must also be acknowledged.

Perhaps led by King Erik of Sweden and Bishop Henry of Uppsala, the first organized mission allegedly arrived in Finland proper in sakakunta, in the southwest of the country, and offered the Christian faith to the Finns. When the Finns refused to convert, a battle resulted. Ultimately, King Erik prevailed and the Finns were forced to accept Christianity. At this time, many Finns were supposedly baptized. After King Erik's victory and mass conversion, he returned to sweden, while legends claim that Bishop Henry remained in Finland and devoted himself to preaching. Bishop Henry was not there very long, though.

\footnotetext{
13 C.J.A. Oppermann, page 174 and 200.

${ }^{14}$ C.J.A. Oppermann, page 200.

15 Birgit Sawyer, page 31.
} 
According to stories, Bishop Henry suffered the death of a martyr soon after King Erik's departure. Despite claims of Henry's early death, if the mission ever existed, st. Henry and King Erik were instrumental in introducing to Finland an organized church and an ally with the Swedish state. ${ }^{16}$

The time st. Henry spent in Finland is unknown as some historians claim six months and others claim a couple years. In both versions of the story of the bishop, st. Henry was martyred at the hands of a Finnish convert, Lalli, on the icy Lake Koyiuo on the island of Kirkkosaari. Lalli is a Christian name short for Lars Laurentius, which comes from St. Laurentius. The Christian references in both accounts, however vague, indicate that there is some Christian influence in the legend. However, there are two very different versions of the death of st. Henry. The ecclesiastical version of the story claims that Lalli killed st. Henry because Henry imposed a heavy penance, including excommunication, upon Lalli for his murder of a Swedish soldier. ${ }^{17}$ This version presents Lalli as resisting an established moral and legal order, thus implying that the Finns had some difficulty with converting to Christianity. The Finnish Ballad version, which may date back to the thirteenth century, although the earliest

${ }^{16}$ C.J.A. Oppermann, page 200-204. 
manuscript is from the seventeenth century, tells that Lalli was angry because the bishop forced his wife to extend hospitality to Bishop Henry and his servant. Upon returning home, Lalli was furious to discover his wife being forced to feed the bishop and his servant. In a fit of rage, Lalli supposedly murdered the bishop. ${ }^{18}$ In this episode, Lalli's action indicates the Finn's natural reaction to revolt against the secular administrative powers of the Church. This account highlights the problems with the organization of the church and may have been written by a disgruntled priest. The ballad, written in Kalevala metre, is not of folk origin, and was probably written by a priest. ${ }^{19}$ However, as there is little historical evidence about this period in Finland, there is no actual proof of either story and both accounts, while providing some insight as to the Finn's initial difficulties with embracing Christianity, have prejudices.

Rome is vague on the subject of these missions and the general time period in Finland. The first reference to Finland appears in a papal bull issued in 1172 by Alexander III to Archbishop Stephen, his suffragans, and Jarl

17 This version is told during the mass honoring St. Henry.

18 Lehtonen, page 22 .

19 Lehtonen, page 22 .

Kalevala is Finland's national epic - a collection of Finnish folk poetry collected by Elias Lonnrot in the nineteenth century. 
Guttorm. The Bull refers to the Finns as a part of the Christian realm, but admonishes them for their lack of obedience. ${ }^{20}$ Apparently the Finns, like other pagans, sought Christianity when it was convenient for them but otherwise ignored their duty to the Church. When times were bad, the superstitious Finns accepted the new faith, but once things settled the Finns would revert to the pagan ways of life. Another papal bull mentioning Finland was issued in 1209 by Innocent III, who advised the archbishop of Lund on the appointment of bishops to Finland. ${ }^{21}$ Although rarely mentioned, Finland was clearly considered in the realm of Christendom by the thirteenth century.

Although not mentioned in the pronouncements, Bishop Henry is said to have been canonized in 1158 by Pope Adrian IV (formerly Cardinal Breakspeare) and is the patron saint

${ }^{20}$ C.J.A. Oppermann, Page 200 and 205.

Pope Alexander III Papal Bull

Sv. Dip., No. 59 Sv. Tr., No. 46; Celse: "Bullarium," p. 41; Ornhjalm: "H.E.," IV., V., p. 491; P.L. 200, Alexander III., E. and P., No. 976; Jaffe, No. 12114. Dated Sept. 9, 1171-2. Tuscalanum. "Phinni simper, imminente sibi exercitu inimicorum, fidem servare christianam promittunt et praedicatores et eruditores christianae legis desideranter requirunt, et recendente exercitu fidem abnegant, praedicatores contemnunt et graviter persequuntur."

21 C.J.A. Oppermann, page 207.

Pope Innocent III Papal Bull

Sv. Dip., No. 136; Celse: "Bullarium," p. 52; F.M.U., No. 48; P.L. 216, Reg. Innocent III., Book XII., No. 102; Botthast, No. 3807. Dated Oct. 30, 1209. Lateran.

"Nam cum propter novellam plantationem et ejusdem regionis hominum pertinaciam ac loci etiam intemperiem electus ibidem non ad honorem assumptus sed expositus martyrio reputetur, nullus fere ad illius regimen sedis aspirat nisi qui divini verbi zelo succensus pati exoptat pro Christi nominee cruciatus." 
of Finland. ${ }^{22}$ However, no documents have been preserved of the canonization of st. Henry and many questions exist as to the assertion that Pope Adrian IV was responsible for his canonization. The only reference of the Bishop is in an indulgence letter by Boniface VIII written in 1296 stating the cathedral of Abo (Turku) was dedicated to St. Henry ${ }^{23}$

Bishop Henry's successor, Rudolfus suffered the death of a martyr sometime around 1178 after an attack by the Russians and Karelians of southeastern Finland. Folkvin, who followed Rudolfus, also had problems with the unruly Eastern Finns who, with their Russian allies, burned Abo in 1198. It is unclear if Folkvin was killed in those attacks. ${ }^{24}$ These uprisings hindered Christianity's progress in Finland.

Pope Innocent III's reign from 1198 to 1216 marked the highpoint of medieval papal influence, and the powerful pope encouraged missionaries to the North. With papal support from Rome and a rivalry stirring between the East and West, missions began to flourish in Finland. In the thirteenth century, both the kingdom of Sweden, supported

\footnotetext{
22 C.J.A. Oppermann, page 204.

23 C.J.A. Oppermann, page 204.

Boniface VIII Date May 10, 1296. Rome.

"Cupientes igitur ut Ecclesia Aboensis, in honorem b. Marie Virginis et Sancti Henrici Episcopi et Martiris fundata ...."
} 
by Rome, and the Principality of Novgorod, supported by the Greek Orthodox Church, extended their influence into Finland. The city of Novgorod had adopted Christianity and it is known that the city many contacts with the Finns. In 1227, Yaroslav, Duke of Novgorod, was still sending priests to Karelia to help convert the Karelians of eastern Finland. ${ }^{25}$ However, because of Finland's close association with the see of Lund, Finland's transformation to Christianity was probably also influenced by German and Danish missionaries from Hamburg-Bremen.

In the early thirteenth century, Finland was just another outpost of the see of Lund, the dominant diocese in northern Europe throughout the medieval era. ${ }^{26}$ However, Finland became more independent in 1220 with the arrival of Bishop Thomas, an English clergyman from Uppsala. Bishop Thomas, a Dominican, had a large library and ties to the University of Paris. ${ }^{27}$ His reign marked the arrival of the western scholarly culture in Finland. During Thomas' episcopacy, the see was moved from Pantemakoi to Abo.

Not all Finns were initially ready to abandon their pagan ways and convert, and a resistance was formed. In

24 C.J.A. Oppermann, page 206.

25 C.J.A. Oppermann, page 208.

${ }^{26}$ This was true even after Norway gained its archbishopric in Nidaros in 1152 and Sweden attained its archbishopric in Uppsala in 1164.

27 Lehtonen, page 29. 
1238, Jarl Birger led an expedition to crush a rebellion started by the Hamalaiset in $1237 .{ }^{28}$ By 1239 the rebellion was crushed and Hame began to accept Latin Christianity. By the end of Thomas' reign as bishop of Turku in 1245, western Finland was largely Christian and virtually autonomous, free from the control from the see of Lund and under the direct authority of Rome.

However, even at this time, Christianity was not wholly accepted in Finnish society. In 1278 Karelia remained under the see of Novgorod. Sweden continued to provide missionaries from the West. In 1293, Sweden sent Torgils Knuttson to bring Karelia within their control. This is commonly referred to as the third Crusade in Finnish history, and it brought all of Finland under Sweden's influence. Finally, at the end of the thirteenth century, Finland began to accept western Latin Christianity into its culture. ${ }^{29}$

As is true with most Northern European countries, in Finland, Christianity played a substantial part in the westernization of the country. However, it is important to point out, as explained by Else Roesdahl,

\footnotetext{
28 Paula Purhonen, Page 192.

${ }^{29}$ Lehtonen, page 24 .
} 
The conversion of Finland involved a people with a quite different religion, language, and culture from Denmark, Norway, and Sweden. ${ }^{30}$

Because Finland is more isolated geographically and culturally and had more scattered tribes than the rest of northern Europe, Finns took longer to accept Christianity and the resistance was quite bloody. However, it can be said that the influx of Christianity assisted Finland's assimilation into the western world. With the adoption of Christianity in Finland, there was a clear change in the cultural beliefs held by the Finns. Not only did the Finns accept the new religion, but they also began to enjoy the scholastic and economic accomplishments of western Christian civilization. However, not all historians believe Finland's assimilation into western culture was a positive occurrence:

The illusion that Christianity saved the Finns from the darkness of a terrible paganism and brought them all the benefits of civilization is a great error. The conversion signified the destruction of the original Finnish traditions and their submergence under the mass culture of Christian Europe. The Swedish conquest was not so dangerous - the Finns had lived with the swedes for many centuries. But the Christian church crushed the self-esteem of the Finns, which was based on confidence in their own magic and in the help of their dead ancestors. During the Viking Period the Finns could still hold their own because their neighbors were afraid of their magical powers. When these were declared to be sins and temptations of the Devil, leading directly to eternal

${ }^{30}$ Birgit Sawyer, page 2. 
damnation, the shock was so great that the Finns have not yet fully recovered, even today. ${ }^{31}$

Although an interesting analysis, this view is rather extreme and reads like much of the revisionist hypernationalist pseudo-historical views that have become all too prominent in modern European historiography. Whether the entry of Christianity was ultimately beneficial to the Finns or not, the facts remain that they still embraced the new religion, culture and way of life.

31 Birgit sawyer, page 34-35. 


\section{CHAPTER 7}

CONCLUSION

Through the conversion, the Scandinavian monarchies developed, the Icelandic parliament became stronger, and Finland organized and opened its doors to influence from foreign powers. Political factors were critically important in the conversion of Scandinavia, Iceland and Finland. Scandinavia in general was ruled by numerous independent chieftains. As Viking leaders converted abroad returned home to exert their influence, Christianity became more widely accepted in pagan areas. As their rulers sought a greater more meaningful connection to the wider Christian world beyond, Scandinavian kingdoms began to convert. At times, to aid the conversion process, the Scandinavian leaders imposed the faith on their kingdoms. Through this process, Scandinavian royalty was able to control the statebuilding occurring simultaneously. However, leaders were by no means the only stimulus to conversion, each region had specific stimuli as well. Pressure from international alliances prompted the Danes to 
accept Christianity while helping Danish leaders maintain political power and keeping Danish politics free of foreign dominance. Iceland converted as a way to gain social polity. Norway converted to set itself apart from the scandinavian countries that were slower to convert. The Swedes, the last of the Germanic peoples to convert, sought to keep foreign powers from infiltrating their political system through the acceptance of Christianity. Finland converted last, following in the footsteps of Scandinavia. Because the Northern Europeans were so fiercely independent and leery of outside domination, any outside influx of religious power of was seen as a threat to their sovereignty. As a result, Christianity became accepted only after individual leaders were converted and once foreign missionaries were no longer seen as a political threat.

Christianity had a powerful, structured Church centered on an ideology and beliefs with which the Scandinavians could identify. Scandinavian kings capitalized on the opportunity to unify their own states by utilizing the organizational power of the Church introduced to them by their relations with Christian leaders from England, France, and Germany. The success of Christianity in Northern Europe is verified by the implementation of 
ecclesiastical structures and organizations such as the royally supported building of churches, creation of bishoprics, and ultimately, the implementation of tithes. Clearly, missionary work and politics were closely connected throughout Scandinavia.

Foreign contributors from English, Frankish, and German missionaries were very important in the conversion process, yet it is impossible to determine the impact that Christian preaching had on the Scandinavians. However, it is clear that the independent nature of the Northern Europeans was taken into consideration by the missionaries as it was common throughout the North for the church to allow pagan ideas and practices to be incorporated into Christian customs. As the Viking plan of attack centered on consistency and aggressiveness, the missionaries were also relentless with their attempts to convert any scandinavian audience, at times reverting to purchasing slaves merely for the purpose of teaching them Christianity. The missionary work in the North started with the Anskar, a Frankish bishop, and continued well into the twelfth century with the activities of English Cardinal Nicholas Breakspeare. However, the incorporation of Scandinavian and Christian England into a larger North Sea empire in the 
time of svend and Canute was also important in the conversion process.

The conversion to Christianity in the northern areas of Europe was gradual but inevitable. As Europeans began to interact with Northern tribes through trade, Christianity introduced Roman culture to the Northern Europeans and brought new political structures to these countries. The development of these countries into western standards indicated their desire to connect to the world outside of Scandinavia away from their raiding and plundering missions. Ultimately, the acceptance of Christianity calmed the Northern Europeans' antagonistic ways as they accepted Christian culture as a part of their own. 


\section{REFERENCES}

Adam of Bremen. History of the Archbishops of HamburgBremen. Translated by Francis J. Tschan. New York: Columbia University Press; 1959.

Anderson, Ingvar. A History of Sweden. London: Weidenfeld and Nicolson; 1956.

Andersson, Theodore M. \& William Ian Miller. Law and Literature in Medieval Iceland. Sanford, Califonia: Sanford University Press; 1989.

Adalsteinsson, Jon Hnefill. Under the Cloak: The Acceptance of Christianity in Iceland with Particular Reference to the Religious Attitudes Prevailing at the Time. Uppsala: Uppsala University; 1979.

Arent, A. Margaret, trans. The Laxdoela Saga. New York: The American-Scandinavian Foundation; 1964.

Barker, William P. Who's Who in Church History. Old Tappan, New Jersey: Fleming H. Revell Company; 1969.

Boyesen, Hjalmar. Norway. New York: G.P. Putnam's Sons; 1904 .

Bryce, James. Studies in History and Jurisprudence. Vol. I \& II. New York: Oxford University Press; 1901.

Butler, Ewan. Scandinavia. New York: American Heritage Publishing Co., Inc.; 1973.

Byock, Jesse L. Medieval Iceland: Society, Sagas, and Power. Berkeley: University of California Press; 1.988 .

Dasent, Sir George Webbe. The Story of Burnt Njal: From the Icelandic of the Njals Saga. New York: E.P. Dutton \& Co.; 1900. 
Davidson, Linda Kay and Maryjane Dunn-Wood. Pilgrimage in the Middle Ages: A Research Guide. New York: Garland Publishing, Inc.; 1993.

Deanesly, Margaret. A History of the Medieval Church: 590-1500. London: Methuen \& Co. Ltd; 1959.

Deanesly, Margaret. The Pre-Conquest Church in England. New York: Oxford University Press; 1961.

Derry, T.K. A History of Scandinavia: Norway, Sweden, Denmark, Finland, and Iceland. Minneapolis: University of Minnesota Press; 1979.

Derry, T.K. A Short History of Norway. Westport: Greenwood Press Publishers; 1968 .

Duckett, Eleanor. The Wandering saints of the Early Middle Ages. New York: W.W. Norton and Company, Inc.; 1959.

Dunham, S. A. History of Denmark, Sweden, and Norway. London: Longman, Orme, Brown, Green \& Longmans; 1839.

Durrenberger, E. Paul. The Dynamics of Medieval Iceland. Iowa City: University of Iowa Press; 1992.

Einarsson, Stefan. A History of Icelandic Literature. New York: The Johns Hopkins Press; 1957.

Fell, Michael. And Some Fell into Good Soil: A History of Christianity in Iceland. New York: Peter Lang; 1999.

Gelsinger, Bruce E. Icelandic Enterprise: Commerce and Economy in the Middle Ages. Columbia, SC. University of South Carolina Press; 1981.

Gerhardsson, Birger. Memory \& Manuscript: Oral Tradition and Written Transmission in Rabbinic Judaism and Early Christianity. Grand Rapids: William B. Eerdmans Publishing Company; 1998.

Gjerset, Knut. History of Iceland. New York: The MacMillan Company; 1925. 
Glob, P.V. Denmark: An Archaeological History from the Stone Age to the Vikings. Ithaca, New York: Cornell University Press; 1967.

Hastrup, Kirsten. A Place Apart: An Anthropological study of the Icelandic World. Oxford: Clarendon Press; 1998 .

Hastrup, Kirsten. Culture and History in Medieval Iceland: An anthropological analysis in Medieval Iceland. Oxford: Clarendon Press; 1985.

Headley, Rev. P.C. The Island of Fire: A Thousand Years of Old Northsmen's Home - 874-1874. Boston: Lee and Shepard; 1874 .

Johnson, Sveinbjorn. Pioneers of Freedom: An Account of the Icelanders and the Icelandic Free State 874-1202. Boston: The Stratford Company; 1930.

Jones, Gwyn. A History of the Vikings. Oxford: Oxford University Press; 1984.

Jutikkala, Eino. A History of Finland. New York:

Frederick A. Praeger; 1962.

Kallas, Hillar and Sylvie Nickels. Finland: Creation and Construction. New York: Frederick A. Praeger; 1968.

Kendrick, T.D. A History of the Vikings. New York: Charles Scribner's Sons; 1930.

Kjersgaard, Erik. A History of Denmark. Copenhagen: Royal Danish Ministry of Foreign Affairs; 1974.

Klindt-Jensen, ole. Denmark: Before the Vikings. London: Jarrold and Sons, ltd; 1957 .

Larsen, Karen. A History of Norway. Princeton: Princeton University Press; 1948.

Larson, Laurence Marcellus. Canute the Great 995-1035.

New York: The Knickerbocker Press; 1912.

Lindroth, Hjalmar. Iceland: A Land of Contrasts. Princeton: Princeton University Press; 1937. 
McGrew, Julia H. Sturlunga Saga: Volume I The Saga of Hvamm-Sturla and The Saga of the Icelanders. New York: Twayne Publishers, Inc.; 1970.

Mead, W. R. Finland. New York: Frederick A. Praeger, Publishers; 1968.

Miller, William Ian. Bloodtaking and Peacemaking: Feud, Law, and Society in Saga Iceland. Chicago: The University of Chicago Press; 1990.

Mitchell, P. M. A History of Danish Literature. Copenhagen: Gyldendal; 1957.

Monroe, w.S. In Viking Land. Norway: Its People, Its Fjords and Its Fjelds. Boston: L.C. Page and Company; 1908

Oakley, Stewart. A Short History of Denmark. New York: Praeger Publishers; 1972.

Olrik, Axel. The Heroic Legends of Denmark. New York: The American-Scandinavian Foundation; 1919.

Opperman, C.J.A. The English Missionaries in Sweden and Finland. New York: The MacMillan Company, 1937.

Palsson, Hermann and Paul Edwards, trans. Landnamabok: The Book of Settlements. Manitoba: University of Manitoba Press; 1972 .

Popperwell, Ronald G. Norway. New York: Praeger Publishers; 1972 .

Rosedahl, Else. The Vikings. London: The Penguin Press; 1987.

Ross, Margaret Clunies, ed. Old Icelandic Literature and Society. Cambridge: Cambridge University Press; 2000 .

Rumble, Alexander R., editor. The Reign of Cnut: King of England, Denmark, and Norway. London: Leichester University Press; 1994.

Rying, Bent. Denmark: Introduction and History. Copenhagen: The Royal Danish Ministry of Foreign 
Affairs Press and Cultural Relations Department; 1981 .

Sawyer, Birgit, Peter Sawyer, \& Ian wood, ed. The Christianization of Scandinavia. Alingsas, Sweden: Viktoria Bokforlag; 1987.

Sawyer, Peter, editor. The Oxford Illustrated History of the Vikings. Oxford: Oxford University Press; 1997.

Saxo Grammaticus. The First Nine Books of Danish History. Translated by Oliver Elton. London: David Nutt; 1894.

Scherman, Katharine. Daughter of Fire: A Portrait of Iceland. Boston: Little, Brown and Company; 1976.

Scobbie, Irene. Sweden. New York: Praeger Publixhers; 1972 .

Scott, Franklin D. Scandinavia. Cambridge: Harvard University Press; 1975.

Scott, Franklin D. Sweden: The Nation's History. Carbondale: Southern Illinois University Press; 1988.

Shetelig, Haakon. Scandinavian Archaeology. Oxford: The Clarendon Press; 1937.

Sinding, Paul C. History of Scandinavia: From the Early Times of the Northmen and Vikings to the Present Day. Pittsburgh: W.S. Haven; 1863 .

Singleton, Fred. A Short History of Finland. Cambridge: The Cambridge University Press; 1998.

Stromback, Dag. The Conversion of Iceland: A Survey. Bristol: Western Printing Services Ltd., 1975.

Stomberg, Andrew A. A History of Sweden. New York: The Macmillan Company; 1931.

Sturlason, Snorre. Heimskringla: The Norse King Sagas. Translated by samuel Laing. London: JM Dent \& Sons. 1930. 
Talbot, C. H., editor and translator. The Anglo-Saxon Missionaries in Germany. New York: Sheed and Ward; 1954

Thorgilsson, Ari. Islendingabok: The Book of the Icelanders. Translated by Halldor Hermannsson. Ithaca, NY: Cornell University Library; 1930.

Thorsson, Ornolfur, ed. The Saga of the Icelanders: A

Selection. New York: The Penguin Group; 2000.

Tschan, Francis J, translator. History of The Archbishops of Hamburg-Bremen by Adam of Bremen. New York: Columbia University Press; 1959.

Webb, Diana. Pilgrims and Pilgrimages in the Medieval West. New York: I.B. Tauris Publishers; 1999.

Wilson, David. The Vikings and their Origins: Scandinavia in the First Millennium. New York: McGraw-Hill Book Company; 1970 .

Wuorinen, John H. A History of Finland. New York: Columbia University Press; 1965.

\section{On-Line Sources}

Bakken, william. King Cnut and the English Church 1014 to 1035

$\underline{\text { http }}$ ://emuseum.mankato.msus.edu/prehistory/vikings/ang saxe.html

Rimbert. Vita Ansgarii http://www. fordham. edu/halsall/basis/asnkar.html

Sturluson, Snorri. Heimskringla http://sunsite.berkeley.edu/OMACL/Heimskringla 
CURRICULUM VITAE

NAME :

Tracy Marie Legel

ADDRESS :

190 St. Matthew Avenue, \#4

Louisville, KY 40207

DOB :

September 17, 1974

EDUCATION: Juris Doctorate

University of Louisville

1998 - 2001

Bachelor of Arts, International studies University of Dayton

1992 - 1995

INTERNATIONAL

\section{EXPERIENCE :}

International Exchange Program

University of Turku

Turku, Finland

Spring 2001

International Studies Program

Chicoutimi, Canada

Summer 1995

Work Exchange Program

Montpellier, France

Summer 1994 